\title{
10. CENOZOIC RADIOLARIANS FROM DEEP SEA DRILLING PROJECT SITES 612 AND 613 (LEG 95, NEW JERSEY TRANSECT) AND ATLANTIC SLOPE PROJECT SITE ASP $15^{1}$
}

\author{
Amanda A. Palmer, Department of Geological and Geophysical Sciences, Princeton University²
}

\begin{abstract}
A major objective of DSDP Leg 95 (New Jersey Transect) was to investigate the effects of eustatic sea-level fluctuation and crustal subsidence on the depositional and erosional patterns of the Atlantic continental margin in the Baltimore Canyon trough area. Deep Sea Drilling Project Sites 612 and 613 were drilled on the New Jersey continental slope and rise during this leg.

A more specific goal of Leg 95 was to investigate calcareous and siliceous microfossil biostratigraphy in order to identify biostratigraphic gaps and to intercorrelate the various microfossil zonations for the New Jersey margin. This study of radiolarians from Sites 612 and 613, and from Atlantic Slope Project (ASP) Site ASP 15, demonstrates that although radiolarians occur throughout the Cenozoic section in this region, they are most useful for biostratigraphic control in the upper Paleogene part of the stratigraphic record. Results of this investigation indicate that several biostratigraphic gaps occur in the Cenozoic sedimentary sequence penetrated by the three drill holes.

Upper Paleogene radiolarians are well preserved, abundant, and diverse. Although some tropical taxa are rare or absent, sufficient age-diagnostic species are present for biostratigraphic determinations. In comparison, lower Paleogene radiolarians are poorly preserved because pronounced silica diagenesis formed porcellanites in some stratigraphic intervals. The Neogene radiolarians faunas are rare and moderately well preserved at all the sites investigated here. Neogene assemblages are dominated by spongodiscids and porodiscids (similar to faunas of modern cold/temperate shelf waters), and contain few taxa useful for biostratigraphic determinations.
\end{abstract}

\section{INTRODUCTION}

Deep Sea Drilling Project Leg 95 contributes to ongoing studies of the depositional, erosional, and subsidence history of the Atlantic continental margin along the New Jersey Transect in the Baltimore Canyon trough area. Although numerous exploratory boreholes and other deep stratigraphic test wells were drilled on this margin to complement extensive regional seismic surveys (Schlee, 1981; Poag, 1985), none involved continuous coring beyond approximately $300 \mathrm{~m}$ sub-bottom. One of the primary goals of Leg 95 , a study of the unconformity record of this passive margin, required long, continuously cored stratigraphic sequences. Site 612 , on the middle part of the continental slope, and Site 613 , on the toe of the upper continental rise, provide this material. Other objectives of the leg were characterization of depositional environments through the stratigraphic section, and intercorrelation of calcareous and siliceous microfossil biostratigraphic zonations.

The abundance, preservation, and diversity of radiolarians and other siliceous microfossils in the New Jersey margin deposits vary a great deal, but often demonstrate inverse relationships to the biogenic calcite component. The siliceous microfossils are important for biostratigraphic and paleoenvironmental information in some stratigraphic intervals where calcareous microfossils are sparse.

\footnotetext{
${ }^{1}$ Poag, C. W., Watts, A. B., et al., Init. Repts. DSDP, 95: Washington (U.S. Govt. Printing Office)

2 Present address: Ocean Drilling Program, Texas A\&M University, College Station, TX 77843-3469.
}

Previous studies have noted radiolarians in certain $\mathrm{Ce}$ nozoic Atlantic margin deposits, both on shore in coastal plain deposits and in offshore sections (Palmer, 1984, 1986; Poag, 1980, 1984; R. N. Benson, personal communication, 1981), but relatively little has been done to evaluate their biostratigraphic and paleoenvironmental significance. In this study, two chief aspects of radiolarians from the New Jersey continental margin are discussed: (1) radiolarian biostratigraphy in this mid-latitude region with respect to previous radiolarian studies in lower and higher latitudes, and (2) general faunal characteristics with possible paleoenvironmental significance.

\section{PROCEDURES}

Samples were obtained during DSDP Leg 95 (New Jersey Transect) from Sites 612 and 613. Samples were also taken from Atlantic Slope Project Site ASP 15, a well drilled in 1967 by a consortium of petroleum companies at a location $6.4 \mathrm{~km}$ southwest of Site 612 (Poag, 1978; 1985). Locations of these sites are indicated in Figure 1.

In general, two samples were examined from each core from Holes 612 and 613 , although four samples per core were examined from the upper Paleogene section of Hole 612 (Cores 612-16 through 612-36). Only one or two samples per core were available from Site ASP 15. Cores from ASP 15 are generally separated by a drilled interval because the hole was not continuously cored.

Conventional radiolarian preparation procedures (as outlined by Riedel and Sanfilippo, 1977) were followed, including disaggregation of the sample, acidification to remove calcium carbonate, and washing through a $63-\mu \mathrm{m}$ mesh sieve. The high clay content of most samples made the disaggregation process difficult, as did the silicified nature of some of the lower Paleogene sediments. In samples with a high content of detrital quartz sand (from the Neogene section), radiolarians were concentrated by swirling the sand fraction in a beaker.

At least two strewn slides of the resulting residue were made for each sample. To aid in the search for zonal indicators, large radiolarians were concentrated by sieving selected samples through a $150-\mu \mathrm{m}$ mesh sieve. Slides were scanned at $250 \times$ for age-diagnostic taxa. 


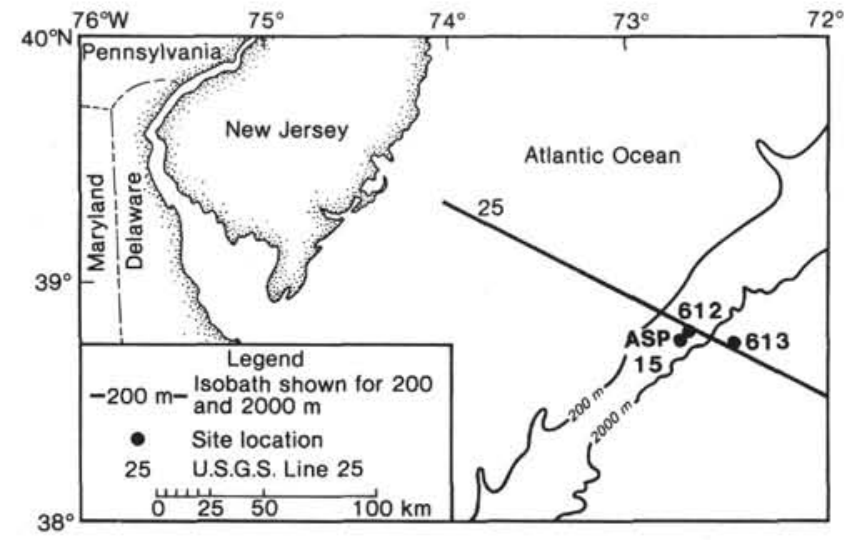

Figure 1. Map of the New Jersey Transect region showing the locations of Leg 95 Sites 612 and 613 and Atlantic Slope Project site ASP 15.

\section{GENERAL OBSERVATIONS ABOUT ATLANTIC MARGIN RADIOLARIANS}

The most diverse, well-preserved radiolarian assemblages in the New Jersey margin occur in upper Paleogene silica-rich nannofossil oozes and nannofossil chalks (Figs. 2-4). Lower Paleogene assemblages may have once been similar, but silica diagenesis caused varying degrees of dissolution and recrystallization of radiolarians in the silica-rich chalks and porcellanites. Age determinations based on radiolarians are difficult to make in the lower Paleogene section, because poor preservation hinders identification of taxa.

The best-preserved, most abundant Neogene radiolarian faunas in the on-shore coastal plain, shelf, and upper rise occur in lower and lower middle Miocene diatomaceous muds (Palmer, 1984, 1986; Poag, 1980; 1985). These units occur at some sites on the New Jersey outer shelf and slope (i.e., the COST B-3 well; Palmer, unpublished data), but were not recovered on Leg 95 (see Poag and Mountain, this volume, for discussion). Neogene radiolarians from New Jersey margin sites are more abundant, in finer-grained sediments relative to the sandier lithologies, but all the Leg 95 Neogene faunas are of low diversity, are poorly preserved, and are dominated by non-age-diagnostic taxa. Upper Pliocene to Pleistocene sediments contain few radiolarians; better preservation and greater abundance occur in muddier lithologies, compared with glauconitic sands. These late Neogene assemblages are of low diversity and contain few to no age-diagnostic taxa.

\section{RESULTS FROM EACH SITE}

Results presented here are based on studies conducted on shore, and in some cases significantly revise preliminary shipboard radiolarian results (site chapters, this volume).

The presence of low-latitude taxa in the Atlantic margin assemblage makes it possible to recognize the standard radiolarian zones of Riedel and Sanfilippo (1978; and subsequent modifications in Saunders et al., 1985), but some uncertainties remain. Many of the nominate and indicator species in the standard radiolarian zonation are absent, or occur so sporadically that they do not provide reliable datums. Further, as discussed later, the sequence of first and last appearances and evolutionary transition events observed in low latitudes (Riedel and Sanfilippo, 1978 and in Saunders et al., 1985) appears to be slightly different in the New Jersey margin section. The use of tropical zones and datums at this mid-latitude location does not allow the stratigraphic resolution possible in lower latitudes. It may be desirable in the future to establish a middle-latitude Atlantic zonation (as suggested by Sanfilippo et al., 1973, with regard to Mediterranean Neogene radiolarians). Such a zonation would be particularly valuable if correlations were made with both Riedel and Sanfilippo's (1978) lowlatitude zonation and Bjorklund's (1976) Norwegian Sea zones.

Correlation of Riedel and Sanfilippo's radiolarian zones (1978; and modifications in Saunders, et al., 1985) with other planktonic microfossil zones and with the absolute time scale is based on the Berggren et al. (1985b) time scale. The Leg 95 shipboard scientific party agreed upon the use of this time scale in reporting all cruise results; this created some difficulty in reporting the age of the Eocene/Oligocene boundary interval, because different ages are assigned to radiolarian zones in this interval by Berggren et al. (1985a, b) and Riedel and Sanfilippo (1978; in Saunders et al., 1985), as discussed below.

Figure 5 indicates the Paleogene radiolarian zones that have been identified at Sites 612 and 613, and their absolute age correlation based on the Berggren et al. (1985a, b) time scale. The correlations used by Berggren et al. $(1985 \mathrm{a}, \mathrm{b})$ change the traditional age assignments of certain zones, such as the Thyrsocyrtis bromia Zone (now subdivided, as explained below). The top of this zone (placed at the evolutionary transition of Lithocyclia aristotelis to L. angusta, and the last morphological appearances of Lophocyrtis jacchia, Lychnocanoma amphitri$t e$, and Dictyoprora pirum) was equivalent to the Eocene/Oligocene boundary, according to Riedel and Sanfilippo (1978). In Saunders et al. (1985), Riedel and Sanfilippo divided the T. bromia Zone (from oldest to youngest) into the Carpocanistrum azyx, Calocyclas ban$d y c a$, and Cryptoprora ornata zones; the top of the $C$. ornata Zone (placed at the evolutionary transition of $\mathrm{Li}$ thocyclia aristotelis to L. angusta and the last morphological appearance of Lophocyrtis jacchia) marks the Eocene/Oligocene boundary. Berggren et al. (1985a), however, review evidence that places the Cryptoprora ornata/Theocyrtis tuberosa zonal boundary near the NP21/ 22 boundary, within the early Oligocene.

Other significant differences involve the placement of the early/middle Eocene and middle/late Eocene boundaries. According to Riedel and Sanfilippo (1978), these fall within the Thyrsocyrtis triacantha and Podocyrtis mitra zones, respectively. In the new time scale the same boundaries occur within the Theocotyle cryptocephala and Carpocanistrum azyx zones (Fig. 5).

\section{Site 612}

Figure 2 indicates the abundance and preservation of radiolarians and the ranges of age-diagnostic species in Hole 612. Table 1 shows the abundance of selected spe- 
cies at a more detailed sampling interval through the upper Paleogene section of Hole 612; this interval contains well-preserved radiolarians, and important biostratigraphic events are recognized. Figure 6 correlates this sequence of events with the tropical sequence observed by Riedel and Sanfilippo (1978 and in Saunders et al., 1985).

\section{Cretaceous}

Cretaceous radiolarians were observed in Sample 61261, CC (569.0 m sub-bottom). Specimens observed included few badly corroded spongodiscids and Dictyomitra sp. cf. D. multicostata. Shipboard nannofossil biostratigraphy assigns a middle Maestrichtian age to this sample.

\section{Lower Eocene}

Radiolarians occur in lower Eocene siliceous chalks and porcellanites from Sample 612-60,CC through Sample 612-46,CC (559.4-424.6 m sub-bottom). Preservation tends to be poor at best, with radiolarians completely dissolved and recrystallized in some samples. Sample $612-59, \mathrm{CC}$ (549.8 m sub-bottom) contains Buryella tetradica and Phormocyrtis striata exquisita, which indicate the Buryella clinata Zone or the Bekoma bidartensis Zone. The Bekoma bidartensis Zone is partly of Paleocene age, but this assignment does not conclusively demonstrate the presence of Paleocene strata at Site 612 .

Samples 612-56,CC through 612-46,CC (521.0-424.6 m sub-bottom) contain poorly preserved specimens of Phormocyrtis striata striata, Periphaena delta, Theocotylissa ficus, Ceratospyris articulata, Buryella clinata, Podocyrtis diamesa, and Lophocyrtis biaurita. The occurrence of these species and the absence of Dictyophimus craticula, Theocotyle cryptocephala, and Dictyoprora mongolfieri suggest placement of this interval into the Phormocyrtis striata striata Zone.

\section{Middle Eocene}

No age-diagnostic radiolarians could be identified from the diagenetically altered interval between Samples 612 $45, \mathrm{CC}$ and $612-36-5,110-112 \mathrm{~cm}$ (414.9-325.6 m subbottom). The Theocotyle cryptocephala and Dictyoprora mongolfieri zones (and thus the lower/middle Eocene boundary) evidently occur in Hole 612 within the zone of poor silica preservation, and cannot be recognized using radiolarians. Shipboard nannofossil and planktonic foraminiferal data and Poag and Low (this volume) place the unconformable lower/middle Eocene contact within Core 612-39 (347.3-357.0 m sub-bottom).

Well-preserved middle Eocene radiolarians first occur in a siliceous nannofossil ooze in Sample 612-36-3, 110$112 \mathrm{~cm}$ (322.6 m sub-bottom), and are found through Sample $612-21, C C$ (183.8 $\mathrm{m}$ sub-bottom). Three zones are recognized in this interval: the Thyrsocyrtis triacantha, Podocyrtis ampla, and Podocyrtis mitra zones.

Sample 612-36-3, 110-112 cm (322.6 m sub-bottom) is the first sample above the porcellanite interval with well-preserved radiolarians. This sample is assigned to the Thyrsocyrtis triacantha Zone on the basis of the presence of Eusyringium lagena, Podocyrtis dorus, and Podocyrtis diamesa. Species restricted to this zone in Hole 612 include Lamptonium fabaeforme chaunothorax, The- ocotyle cryptocephala, and very rare Theocotyle nigriniae.

The Podocyrtis phyxis-to- $P$. ampla transition, which marks the boundary between the Thyrsocyrtis triacantha and Podocyrtis ampla zones of Riedel and Sanfilippo (1978), was not recognized. The boundary between the Thyrsocyrtis triacantha Zone and the overlying Podocyrtis ampla Zone is therefore placed stratigraphically below Sample 612-27,CC (241.4 m sub-bottom), above the first appearance of Eusyringium fistuligerum, and below both the first appearance of Podocyrtis fasciolata and the last appearances of Podocyrtis dorus and Podocyrtis diamesa. In Hole 612 the interval between Samples $612-27, \mathrm{CC}$ and $612-23, \mathrm{CC}$ (241.4-203.0 m sub-bottom) contains the last appearances of Theocotyle conica and Thyrsocyrtis tensa and the evolutionary transition of Eusyringium lagena to E. fistuligerum.

The boundary between the Podocyrtis ampla Zone and the overlying Podocyrtis mitra Zone occurs stratigraphically below Sample $612-23$,CC $(203.0 \mathrm{~m}$ sub-bottom), at the Podocyrtis sinuosa-to-P. mitra evolutionary transition. The interval between Samples 612-23,CC and 612-21,CC (203.0-183.8 m sub-bottom) contains the last appearances of Podocyrtis fasciolata and Thyrsocyrtis hirsuta. However, biostratigraphic events which Riedel and Sanfilippo (1978) observe near the top of the Podocyrtis mitra Zone, such as the Lithapium anoectum-toL. mitra transition and the last appearance of Lophocyrtis biaurita, are not observed in the middle Eocene of Hole 612. Because Lithapium mitra is subordinate in abundance to its ancestor L. anoectum, and Lophocyrtis biaurita is abundant through Sample 612-21,CC (183.0 m sub-bottom), it appears that only the lower portion of the Podocyrtis mitra Zone is present through Sample 612-21,CC (183.8 m sub-bottom).

\section{Upper Eocene (to lower Oligocene?)}

No sample was available from Section 612-21-5, but Poag and Low (this volume) identify a disconformity in this section, marked by a glauconite layer. Sample 612$21-3,110-112 \mathrm{~cm}$ (178.3 m sub-bottom) contains specimens of Lithocyclia aristotelis, Theocyrtis tuberosa, Cryptoprora ornata, Dictyoprora armadillo, Lychnocanoma amphitrite, Lophocyrtis jacchia, Cyclampterium longiventer, Thyrsocyrtis bromia, Thyrsocyrtis tetracantha, Lithapium mitra, Artophormis barbadensis, Dictyoprora pirum, Tristylospyris triceros, and Dictyoprora ovata, which together indicate the Calocyclas bandyca Zone.

The abrupt appearance of upper Eocene radiolarians agrees with Poag and Low's placement of an unconformity between the middle and upper Eocene sediments in Core 612-21. Neither the middle Eocene Podocyrtis chala$r a$ and Podocyrtis goetheana zones nor the late Eocene Carpocanistrum azyx Zone (corresponding to the lower part of the Thyrsocyrtis bromia Zone of Riedel and Sanfilippo, 1978) are present, indicating that a biostratigraphic gap of 5 m.y. (from 42.2 to $37.2 \mathrm{Ma}$ ) exists between the middle and upper Eocene sediments at this site.

The last appearance of Thyrsocyrtis tetracantha in Sample 612-19,CC (164.7 m sub-bottom) marks the top of the Calocyclas bandyca Zone. Samples 612-19-5, 110- 


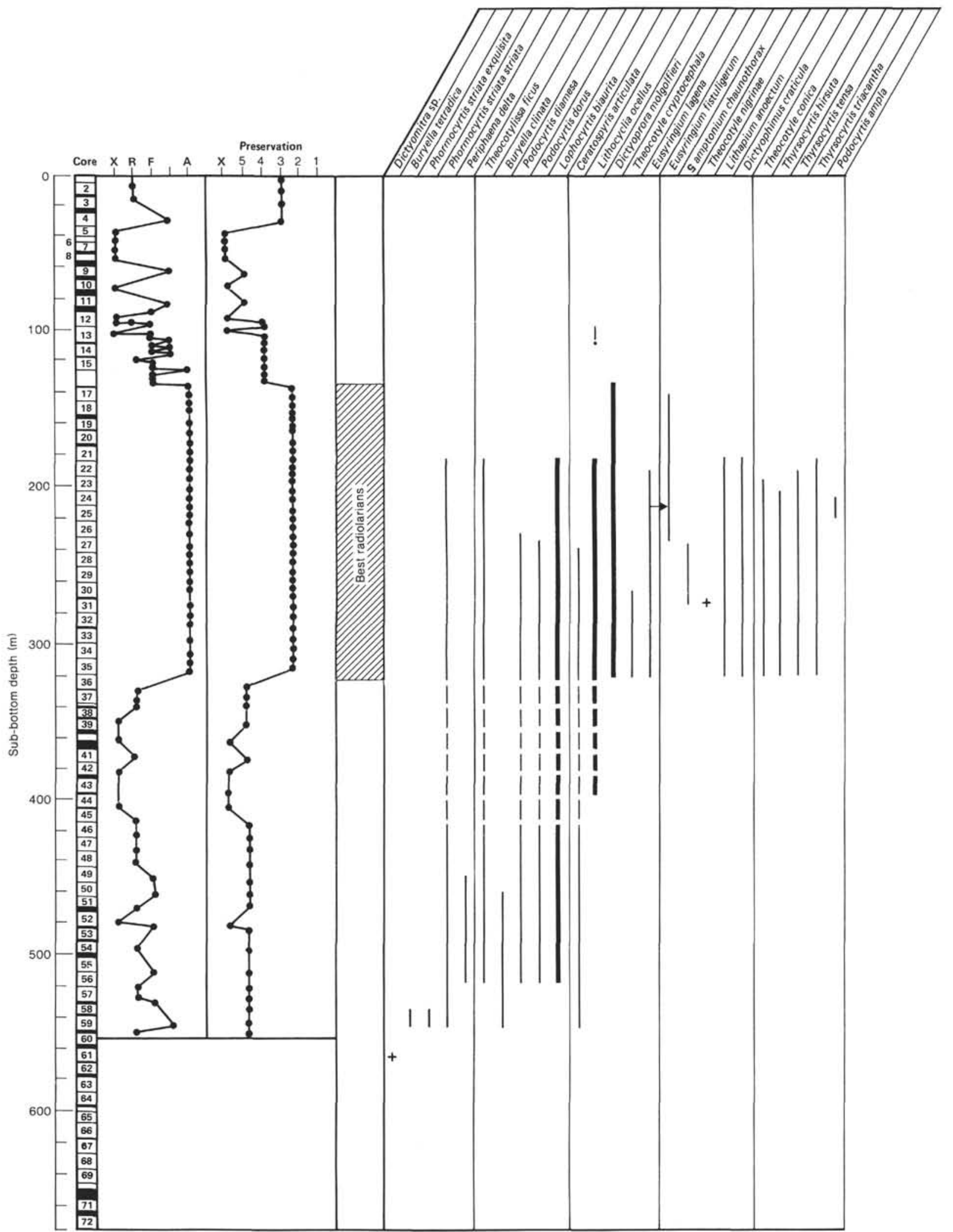

Figure 2. Radiolarian abundance and preservation, ranges of important species, zones, and geologic ages, Hole 612 . Overall abundance is indicated by $\mathrm{A}=$ abundant $\left(10^{4}\right.$ radiolarians per slide $), \mathrm{C}=$ common $\left(10^{3}\right.$ radiolarians per slide $), \mathrm{F}=$ frequent $\left(10^{2}\right.$ radiolarians per slide), $\mathrm{R}=$ rare (10 radiolarians per slide), $\mathrm{X}=$ barren (no radiolarians per slide). Preservation is shown according to the preservation grades of Westberg and Riedel (1978), with $1=$ best preservation and $5=$ worst preservation. More abundant species are indicated by heavier range bars (dashed where radiolarian preservation is poor and/or abundance is low). Isolated specimens of a species are indicated by a plus sign (+). Reworked older specimens are recorded with an exclamation point (!). In recovery column, black indicates unrecovered interval. 
CENOZOIC RADIOLARIANS, LEG 95

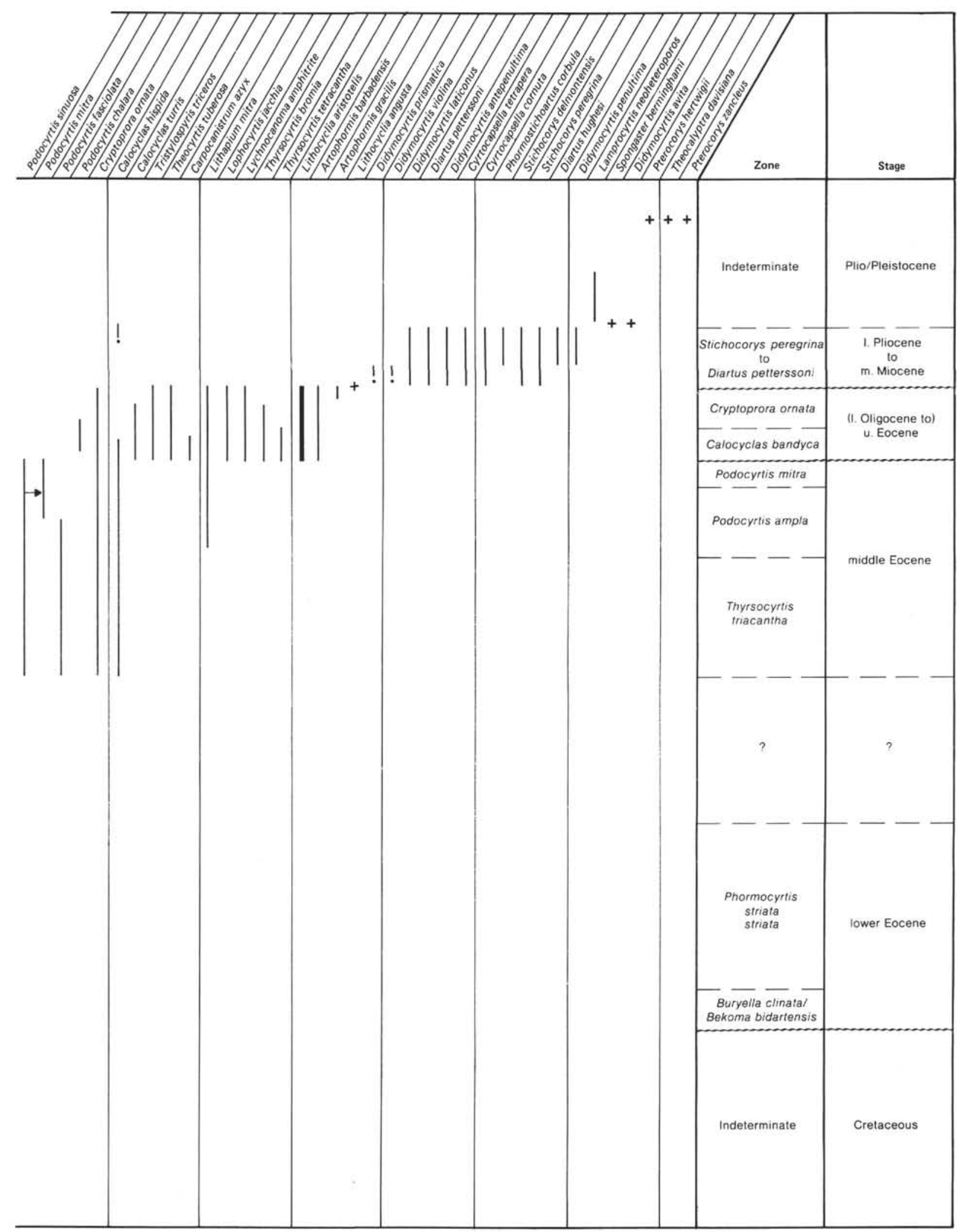

Figure 2 (continued). 


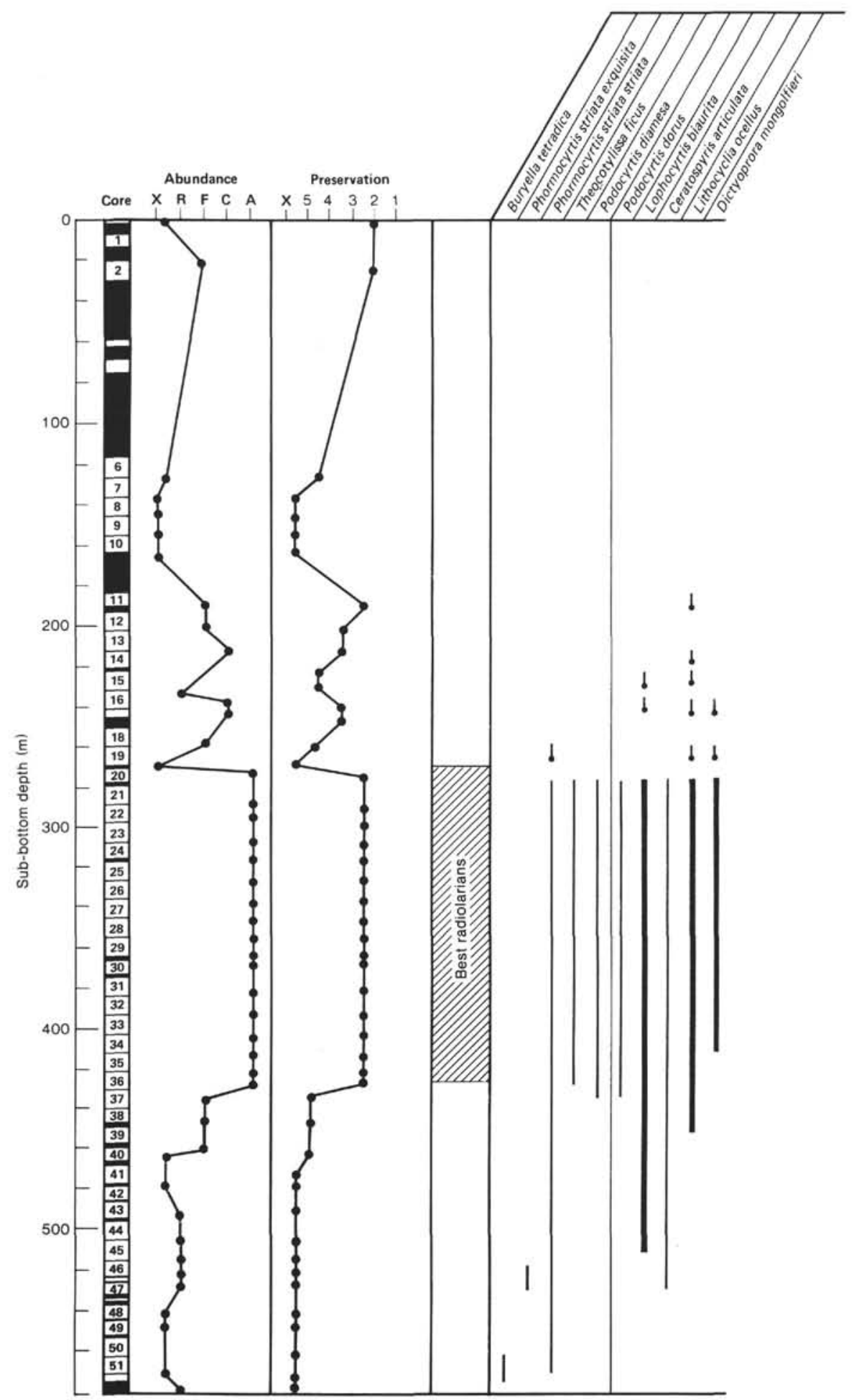

Figure 3. Radiolarian abundance and preservation, stratigraphic ranges of important species, zones, and geologic ages, Hole 613. Symbols the same as for Figure 2.

112 through $612-16, C C$ (162.3-136.2 m sub-bottom) represent the Cryptoprora ornata Zone, which overlies the Calocyclas bandyca Zone.

The appearance of Oligocene species such as Artophormis gracilis in Sample 612-17,CC (145.7 m sub-bottom) and Lithocyclia angusta in Sample 612-17-3, 110-112 $\mathrm{cm}$ (140.3 $\mathrm{m}$ sub-bottom) in subordinate abundance to their respective ancestors, $A$. barbadensis and $L$. aristotelis, suggests that Sample 612-16,CC (136.2 m sub-bottom) can be placed in the upper portion of the Cryptoprora ornata Zone. The Eocene/Oligocene boundary is placed by Berggren et al. (1985a, b) within the Cryptoprora ornata Zone. Therefore, radiolarian biostratigraphic results suggest that the stratigraphic interval from 612 - 


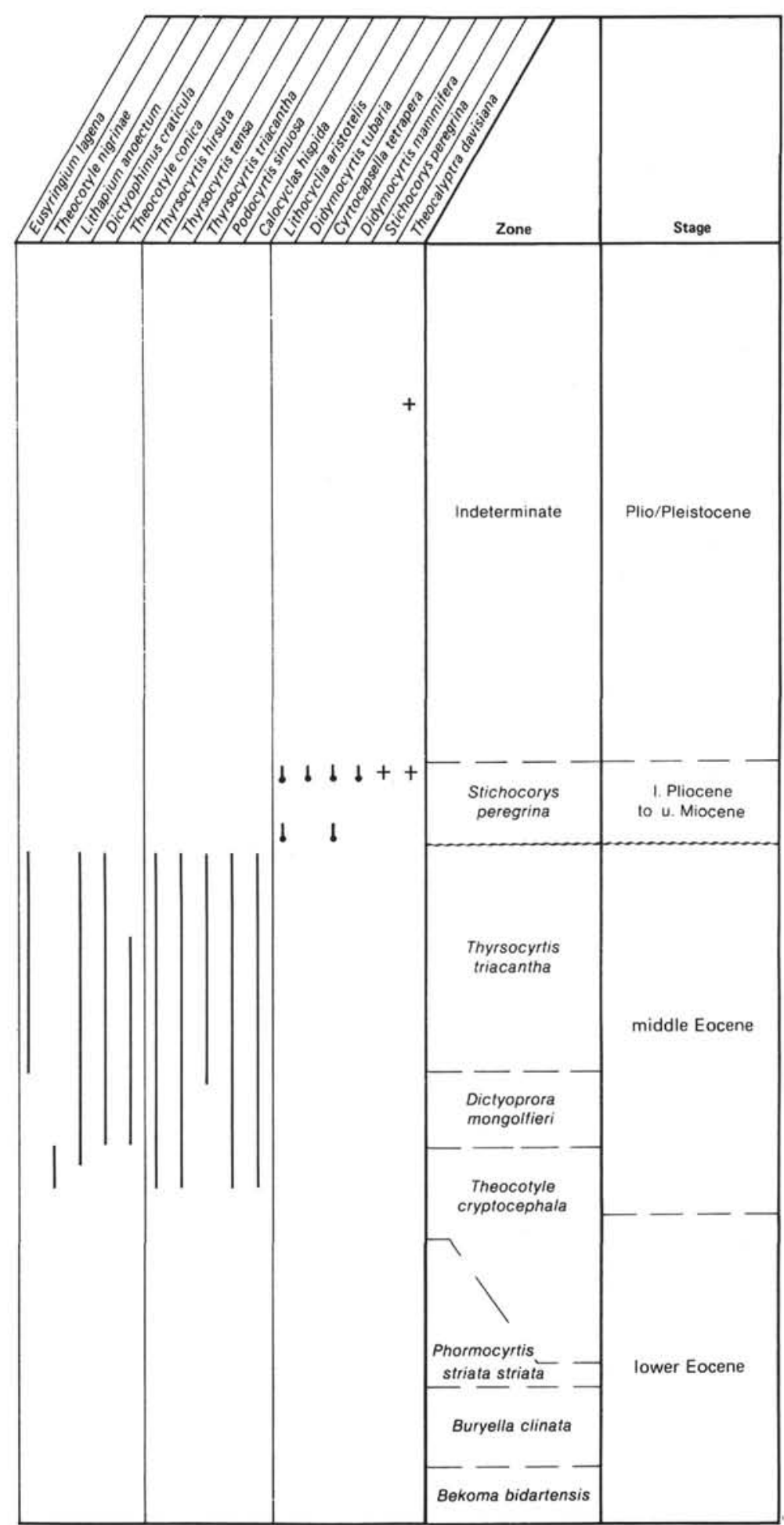

Figure 3 (continued).

$21, \mathrm{CC}$ through $612-16, \mathrm{CC}$ (178.3-136.2 $\mathrm{m}$ sub-bottom) is entirely of late Eocene age, but cannot conclusively demonstrate the presence or absence of lowermost Oligocene deposits in Hole 612. Miller and Katz (this volume) and Poag and Low (this volume) agree that 612$16, \mathrm{CC}$ is of late Eocene age, but recognize a thin overlying Oligocene section.
Table 1 shows the abundances of selected radiolarian taxa in the middle to upper Eocene section of Hole 612. The morphologic tops and bottoms of selected species' ranges, and important evolutionary transitions, are shown. In Figure 6 this sequence of events is compared with the sequence determined by Riedel and Sanfilippo in their biostratigraphic studies of tropical radiolarians (Riedel 


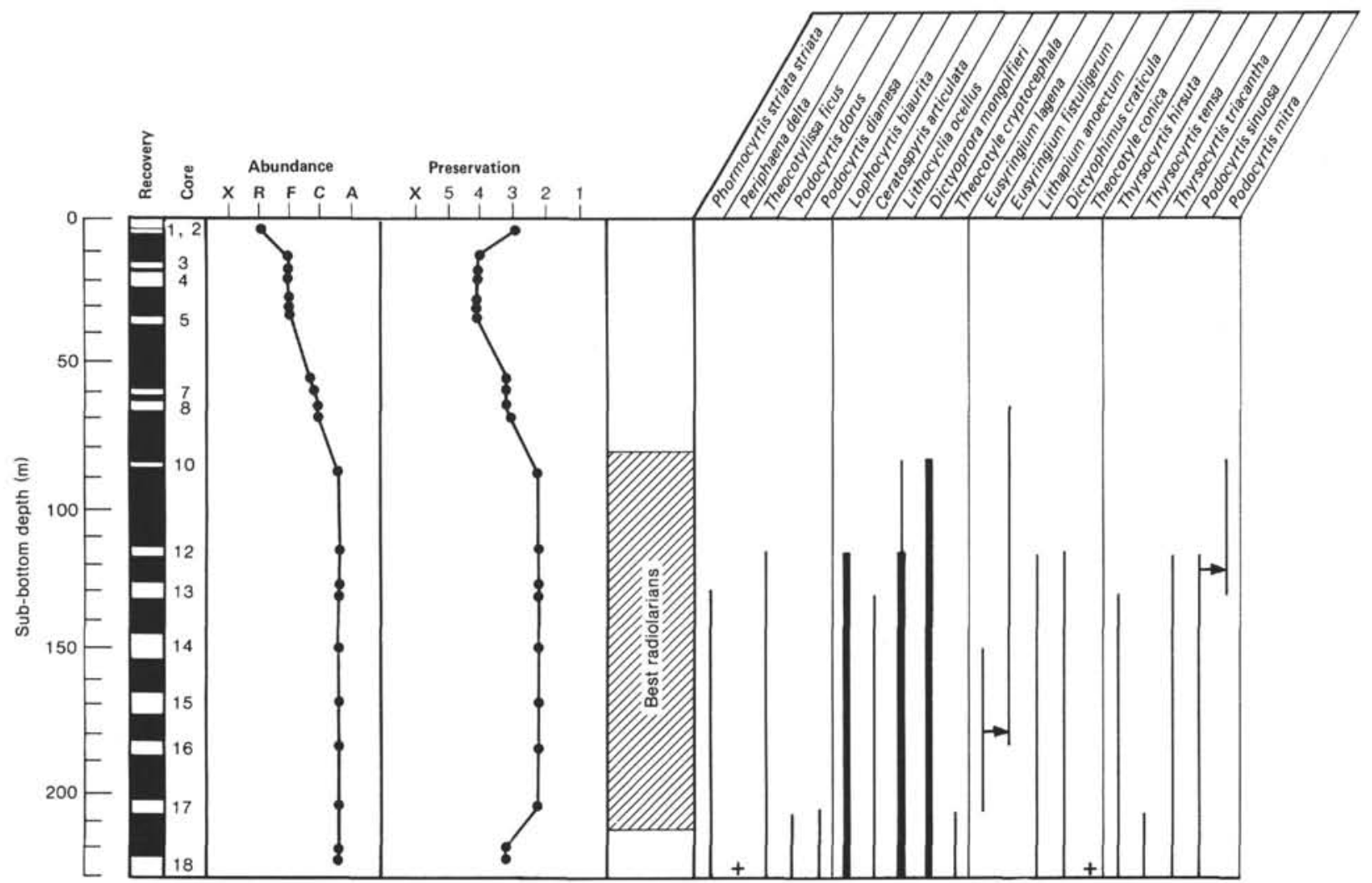

Figure 4. Radiolarian abundance and preservation, stratigraphic ranges of important species, zones, and geologic ages, ASP 15. Symbols the same as for Figure 2.

and Sanfilippo, 1978 and in Saunders et al., 1985). This comparison shows that many of the events known from the tropics were not recognized in the New Jersey margin sedimentary record. Some of the recognized events involve taxa that are rare or occur sporadically, and the reliability of the event as a biostratigraphic datum is consequently reduced. A large number of events are coincident in Hole 612 at the unconformity between the middle and upper Eocene sediments. In general, however, the biostratigraphic events recognized in the New Jersey margin occur in an overall sequence similar to that observed by Riedel and Sanfilippo (1978 and in Saunders et al., 1985) in the tropics.

\section{Upper Miocene to Pliocene}

A major unconformity between the Paleogene and Neogene sections in Hole 612 is marked by the occurrence of sandy, glauconitic sediments overlying siliceous nannofossil ooze in Section 612-16-6 (134.2-135.7 m subbottom) (see Poag and Low, this volume. Neogene radiolarians make an abrupt appearance in Sample 612-16-5, $110-112 \mathrm{~cm}(133.8 \mathrm{~m})$. Although non-age-diagnostic radiolarians dominate the assemblage between Section 612 16-5 and Sample 612-13-5, 110-112 cm (133.8-104.9 m), Diartus petterssoni, Didymocyrtis antepenultima, Stichocorys delmontensis, Cyrtocapsella tetrapera, Phormostichoartus corbula, and specimens of Diartus sp. which appear to be intergradational between $D$. petterssoni and D. hughesi are present. A few specimens of Stichocorys peregrina were also observed, although this occurrence is below the stratigraphic range attributed to S. peregrina by Riedel and Sanfilippo (1978). The majority of these taxa suggest the Diartus petterssoni to Didymocyrtis antepenultima zones. Some poorly preserved and probably reworked lower to middle Miocene taxa, such as Didymocyrtis prismatica and Didymocyrtis violina, occur throughout this interval, although strata of this age were not recognized in Hole 612 .

Radiolarians occur only sporadically in Samples 612$13-5,110-112 \mathrm{~cm}$ through $612-13-1,110-112 \mathrm{~cm}$ (104.9$98.9 \mathrm{~m}$ sub-bottom), and are absent from the glauconitic sand lithologies. The assemblage consists almost entirely of non-age-diagnostic taxa, including Dictyocoryne spp., Eucyrtidium spp., Lynchnocanoma spp., litheliids, pyloniids, actinommids, porodiscids, and other circular spongodiscus.

A few specimens of Stichocorys peregrina, Didymocyrtis penultima, Spongaster berminghami, Didymocyrtis antepenultima, and Stichocorys delmontensis suggest that the interval between Samples 612-13-5, 110-112 cm and $612-13-1,110-112 \mathrm{~cm}$ (104.9-98.9 m sub-bottom) can be assigned to the Stichocorys peregrina Zone or the Didymocyrtis penultima Zone. Diartus hughesi also occurs in this assemblage, although stratigraphically above its range as indicated by Riedel and Sanfilippo (1978). Some reworked middle Eocene radiolarians were noted, including Lithocyclia ocellus and Calocyclas hispida.

Because biostratigraphic markers are rare throughout the interval from Sample 612-16-5, 110-112 through Sample $612-13-1,110-112 \mathrm{~cm}$ (133.8-98.9 m sub-bottom), 


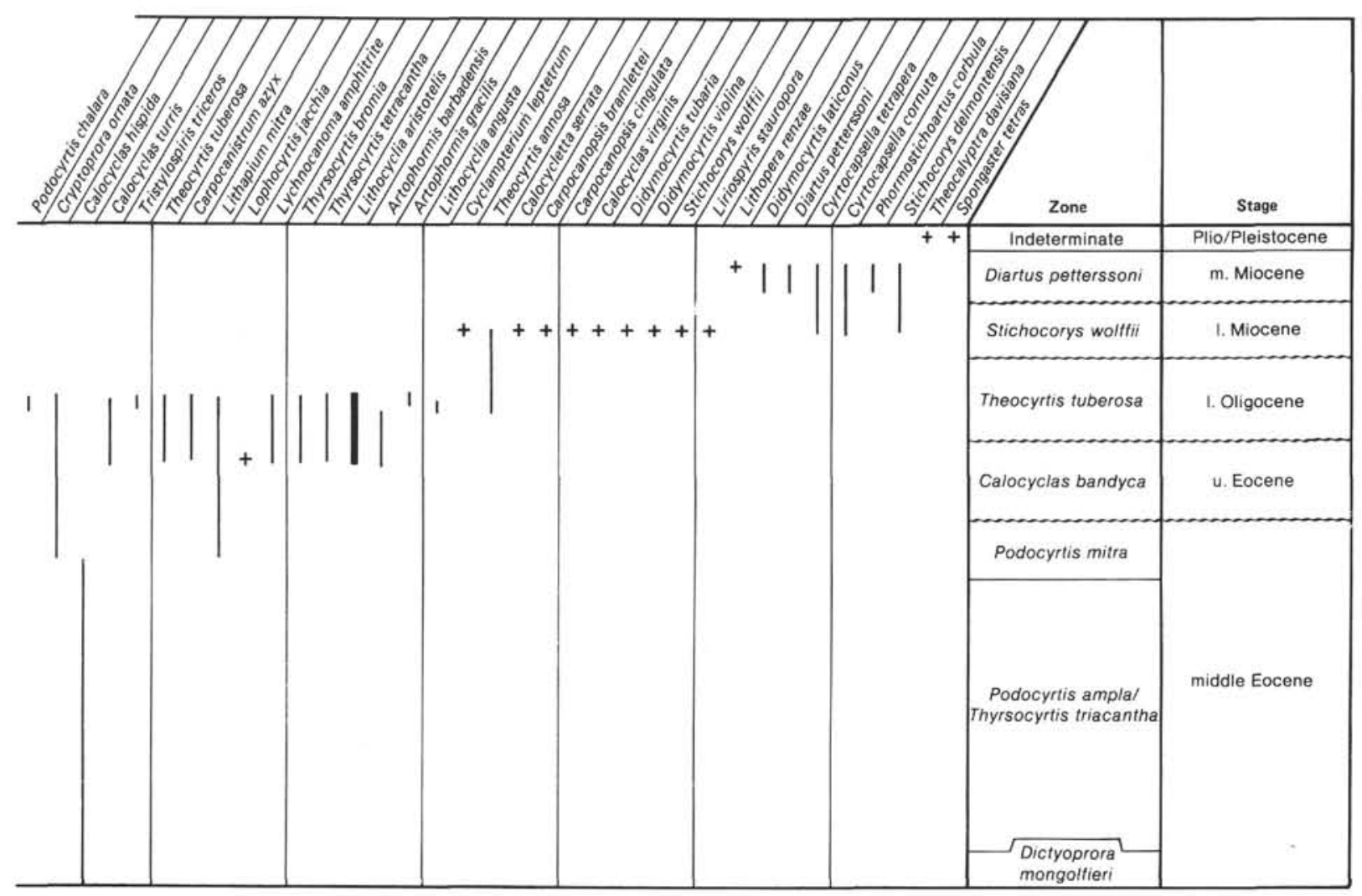

Figure 4 (continued).

the entire interval is assigned to the Diartus petterssoni to Stichocorys peregrina zones.

\section{Pliocene-Pleistocene}

An undifferentiated Pliocene-Pleistocene interval is recognized in sandy, glauconitic muds in Samples 612$12, \mathrm{CC}$ through $612-1, \mathrm{CC}$ (97.8-4.8 $\mathrm{m}$ sub-bottom), on the basis of an extremely sparse radiolarian assemblage. Most taxa, such as Dictyocoryne spp., Eucyrtidium spp., porodiscids, pyloniids, and litheliids, are not age-diagnostic. The few somewhat age-informative taxa include Pterocorys zancleus, Pterocorys hertwigii, Theocalyptra davisiana, and Lamprocyrtis neoheteroporos, which indicate a general Pliocene-Pleistocene age rather than a specific zone. No biostratigraphic gaps could be recognized in the upper Neogene of Site 612 on the basis of radiolarian age data.

An unusual radiolarian fauna occurs in Sample 6124,CC ( $33.6 \mathrm{~m}$ sub-bottom) which contains abundant specimens of Theocalyptra davisiana $(75 \%$ of all radiolarians in the sample) and large centric diatoms. The high abundance of this species has been linked with increased productivity related to Pliocene-Pleistocene glaciation (Morley and Hays, 1979). Furthermore, Benson (1972) noted that this species was "ubiquitous and often dominant in Pleistocene (and glacial Pliocene?) assemblages cored in the North Atlantic on DSDP Leg 12." Its abundance in Sample 612-4,CC thus appears to record a period of increased productivity, possibly associated with a Pliocene-Pleistocene glacial event.
Site 613

Radiolarian abundance and preservation and stratigraphic ranges of important species in Hole 613 are indicated in Figure 3.

\section{Lower Eocene}

As at Site 612, radiolarians at Site 613 are poorly preserved in lower Eocene siliceous chalks and porcellanites, because of silica diagenesis. Age-diagnostic taxa occur only in certain stratigraphic intervals, and age determinations are tentative at best. Buryella tetradica occurs in Samples 613-52,CC through 613-50,CC (581.9-562.9 m sub-bottom), suggesting the Bekoma bidartensis Zone. Phormocyrtis striata exquisita is present in Samples 61347,CC and 613-46,CC (534.4-524.9 m sub-bottom), suggesting the Buryella clinata Zone. In Samples 613-43,CC through 613-35,CC (496.4-421.0 m sub-bottom), Phormocyrtis striata striata without Dictyoprora mongolfieri indicates the Phormocyrtis striata striata Zone or the Theocotyle cryptocephala Zone.

\section{Middle Eocene}

Abundant, moderately well preserved radiolarians occur in Hole 613 in siliceous nannofossil oozes from Samples 613-36,CC through 613-20,CC (440.0-278.6 m sub-bottom). This middle Eocene interval includes the Theocotyle cryptocephala, Dictyoprora mongolfieri, and Thyrsocyrtis triacantha zones.

The Theocotyle cryptocephala Zone (which contains the lower/middle Eocene boundary, according to Berg- 


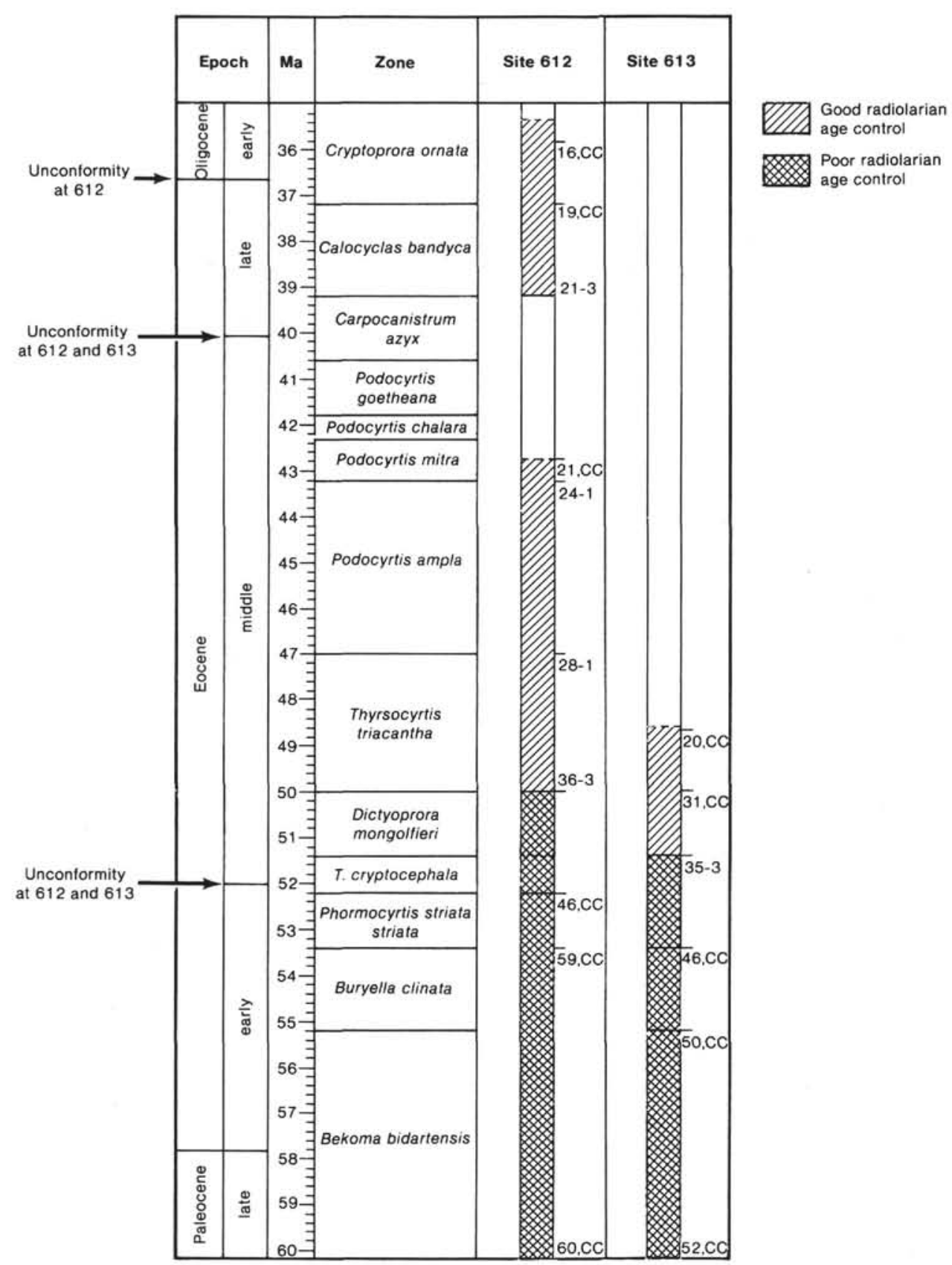

Figure 5. Absolute ages of Riedel and Sanfilippo's tropical Cenozoic radiolarians zones (Riedel and Sanfilippo, 1978; in Saunders, et al., 1985) for the late Paleogene, according to the Berggren et al. (1985) time scale. Intervals with relatively good and poor age control in Holes 612 and 613 are shown. Numbers indicate cores in which certain radiolarian zones were found in each hole. See Poag and Low (this volume) for discussion of unconformities.

gren et al., 1985a, b) occurs below the first occurrence of Dictyoprora mongolfieri in Sample 613-34,CC (411.5 m sub-bottom). The Dictyoprora mongolfieri Zone occurs above this datum, through Sample 613-31-3, 50-52 cm (379.0 m sub-bottom).

The base of the Thyrsocyrtis triacantha Zone is placed at the first morphologic occurrence of Eusyringium lagena in Sample 613-30,CC (374.0 m sub-bottom). The upper part of the zone is apparently not present at the top of the middle Eocene section in Hole 613, because events which occur in the upper part of this zone and the lower part of the Podocyrtis ampla Zone-that is, last appearances of Podocyrtis dorus and Podocyrtis diamesa, and the first morphologic appearance of Eusyringium fistuligerum-were not observed through Sample 613-20,CC (278.6 m sub-bottom).

\section{Neogene}

Radiolarians are sparse in the sandy, glauconitic Neogene sediments of Site 613. Sample 613-19,CC (269.0 m sub-bottom) is barren of radiolarians, and Sample 61318 , CC (259.5 m sub-bottom) contains only reworked Eo- 
cene taxa. The presence of Stichocorys peregrina in Samples 613-17,CC and 613-16,CC (250.0-240.5 m sub-bottom) supports a tentative Stichocorys peregrina Zone assignment. This indicates the presence of a biostratigraphic gap of approximately $31 \mathrm{~m}$.y. between the middle Eocene and the Neogene of Site 613, extending from below the top of the Thyrsocyrtis triacantha Zone (about $48.6 \mathrm{Ma}$ ) to the base of the Stichocorys peregrina Zone (6.2 Ma).

Radiolarians are sparse or entirely absent in the interval from Sample $613-15, C C(231.0 \mathrm{~m})$ to the top of the hole. The only age-diagnostic species present are Pseudocubus sp. in Sample 613-11,CC (193.6 m sub-bottom), and Theocalyptra davisiana in Sample 613-5,CC (115.8 m sub-bottom), both indicating a Pliocene-Pleistocene age. The radiolarian fauna of Sample 613-5,CC is similar to the Theocalyptra davisiana-dominated assemblage at Site 612 in Sample 612-4,CC. Further studies are required to determine whether one or more Theocalyptra davisiana high-abundance horizons exist elsewhere in the New Jersey Transect region.

\section{Atlantic Slope Project Site ASP 15}

Radiolarian abundance and preservation and the stratigraphic ranges of important species are shown in Figure 4.

\section{Middle Eocene}

The middle Eocene interval of ASP 15 is similar to the sections encountered at DSDP Sites 612 and 613; it consists of siliceous nannofossil ooze with abundant and well-preserved radiolarians. Four middle Eocene zones are recognized, as follows:

1. The presence of Periphaena delta, Podocyrtis diamesa, and Podocyrtis dorus, and the absence of Eusyringium lagena in Core 18, indicate the Dictyoprora mongolfieri Zone.

2. Eusyringium lagena appears in Core 17 with Podocyrtis dorus, indicating the Thyrsocyrtis triacantha Zone to lower Podocyrtis ampla Zone.

3. Podocyrtis diamesa and Podocyrtis dorus are absent above Core 17, and the predominance of Podocyrtis sinuosa over Podocyrtis mitra in Cores 16 through 13 indicates the Podocyrtis ampla Zone. The Eusyringium lagena-to- $E$. fistuligerum evolutionary transition evidently occurs between Cores 16 and 15 .

4. The base of the Podocyrtis mitra Zone, the evolutionary transition from Podocyrtis sinuosa to $P$. mitra, is placed between Cores 13 and 12 .

\section{Upper Eocene}

Upper Eocene radiolarians appear in Core 10, including specimens of Lithocyclia aristotelis, Thyrsocyrtis bromia, Thyrsocyrtis tuberosa, Thyrsocyrtis tetracantha, Lychnocanoma amphitrite, Cryptoprora ornata, Lithapium mitra, Lophocyrtis jacchia, Carpocanistrum azyx, Calocyclas turris, Artophormis barbadensis, Thyrsocyrtis bromia, and Dictyoprora amphora, which suggest the Calocyclas bandyca Zone. The Podocyrtis chalara, Podocyrtis goetheana, and Carpocanistrum azyx zones could be present in the unsampled interval between Cores
10 and 12 , although it seems more likely that a disconformity exists between the middle and upper Eocene sediments at ASP 15, similar to that observed at Site 612 .

\section{Lower Oligocene}

Lower Oligocene radiolarians occur in Cores 8 and 7 from ASP 15. Diagnostic taxa present include Lithocyclia angusta, Cyclampterium longiventer, Tristylospyris triceros, Thyrsocyrtis tuberosa, Artophormis gracilis, and Lithocyclia crux, indicating the lower Oligocene Thyrsocyrtis tuberosa Zone. Some upper Eocene taxa occur in these cores, however, including Lithocyclia aristotelis, Cryptoprora ornata, Thyrsocyrtis bromia, Thyrsocyrtis tetracantha, Podocyrtis chalara, Lithapium mitra, and Calocyclas turris, suggesting that the upper part of the Cryptoprora ornata Zone may be present.

\section{Lower Miocene}

As at Sites 612 and 613, the Neogene sediments at ASP 15 are sandier than the Paleogene deposits. Lower Miocene radiolarians appear in Core 5 of ASP 15. The diagnostic species include Carpocanopsis cingulata, Cyrtocapsella tetrapera, Stichocorys wolffii, Cyclampterium leptetrum, Carpocanopsis bramlettei, and Eucyrtidium diaphanes. These taxa indicate the Stichocorys wolffii Zone. There is no indication of the lower Miocene Stichocorys delmontensis, Cyrtocapsella tetrapera zones, although they could possibly occur in the unsampled interval between Cores 5 and 7 .

\section{Middle Miocene}

Cores 3 and 4 contain fewer, less well preserved taxa than the underlying lower Miocene or Paleogene units. Taxa indicating the middle Miocene Diartus petterssoni Zone include Diartus petterssoni, Lithopera renzae, Cyrtocapsella cornuta, Didymocyrtis antepenultima, Stichocorys delmontensis, Cyrtocapsella tetrapera, Phormostichoartus corbula, and Didymocyrtis laticonus. Many nondiagnostic taxa are also present in this assemblage; spongodiscids and actinommids are particularly abundant.

\section{Pliocene-Pleistocene(?)}

As in the Pliocene-Pleistocene sections of Sites 612 and 613, radiolarians in Cores 1 and 2 from ASP 15 are predominantly nondiagnostic for biostratigraphic purposes. Spongaster tetras and Theocalyptra davisiana indicate a general Pliocene-Pleistocene age for these cores.

\section{PALEOENVIRONMENTAL INTERPRETATIONS}

\section{Paleogene}

Radiolarians are abundant and diverse in the middle and upper Eocene and lower Oligocene sediments of Holes 612, 613, and ASP 15, suggesting that bathyal water depths and high rates of biological productivity prevailed on the margin during the late Paleogene. However, certain taxa (notably the genera Podocyrtis, Lamptonium, and Thyrsocyrtis) are rare in the mid-latitude New Jersey margin, compared with lower latitude regions. In the New Jersey margin assemblage, the actinommids, 
Table 1. Abundance of selected species in the upper Paleogene section of Hole 612, where radiolarian abundance and preservation is optimal for making biostratigraphic determinations; morphologic first and last appearances and evolutionary transitions are also indicated.

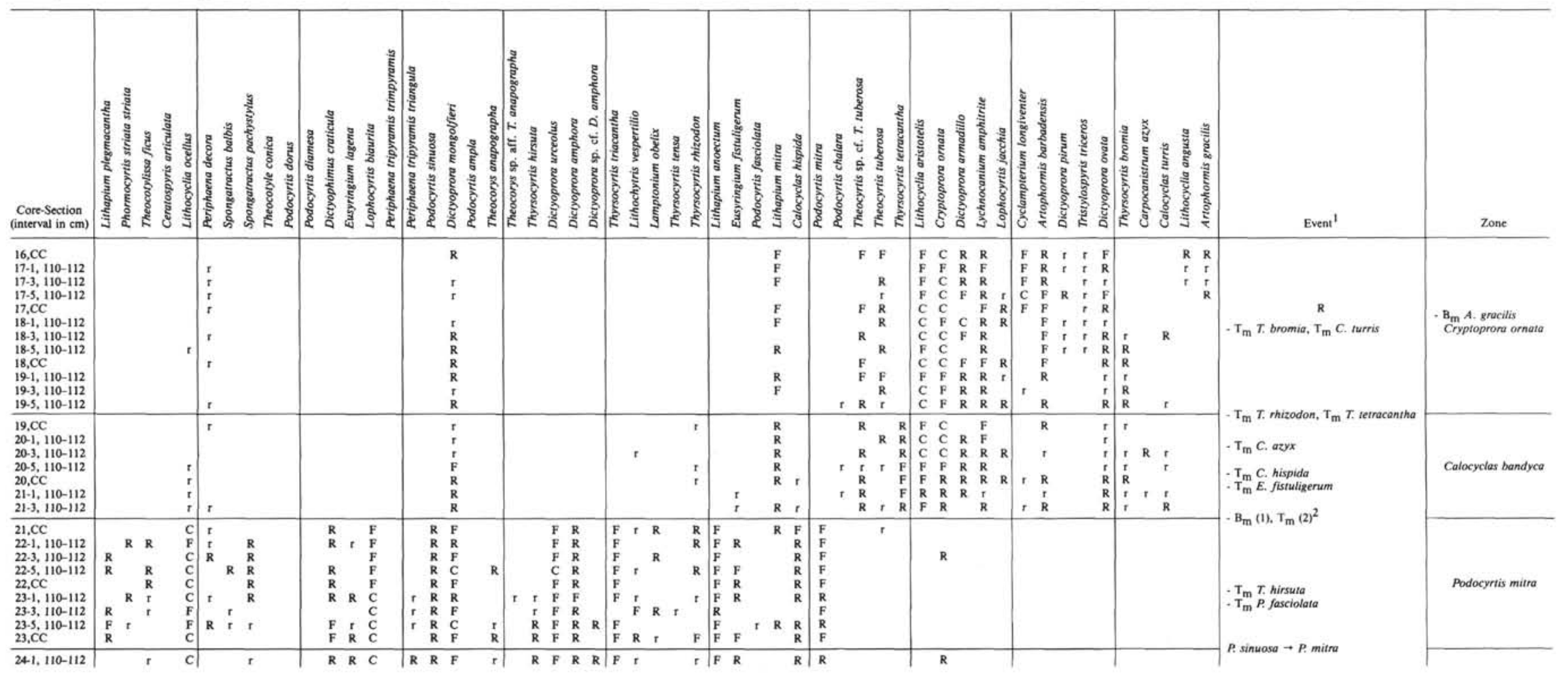




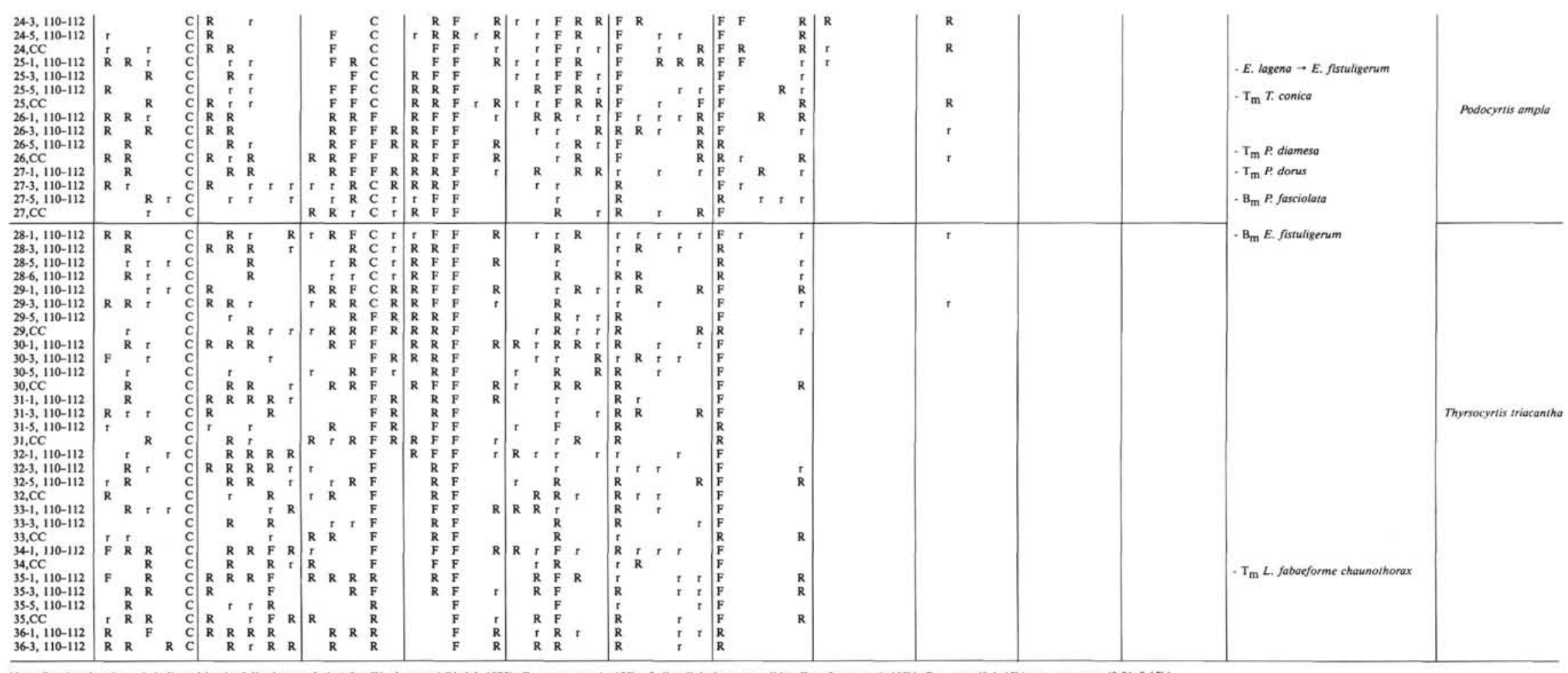

Note: Species abundance is indicated by the following symbols (after Westberg and Riedel, 1978): $\mathrm{C}=$ common (>10\% of all radiolarians on a slide); $\mathrm{F}=$ frequent $(1-10 \%)$; $\mathrm{R}=$ rare $(0.1-1 \%) ; \mathrm{t}=$ very rare $(0.01-0.1 \%)$ ).

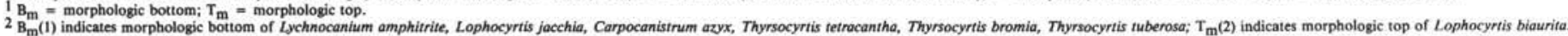




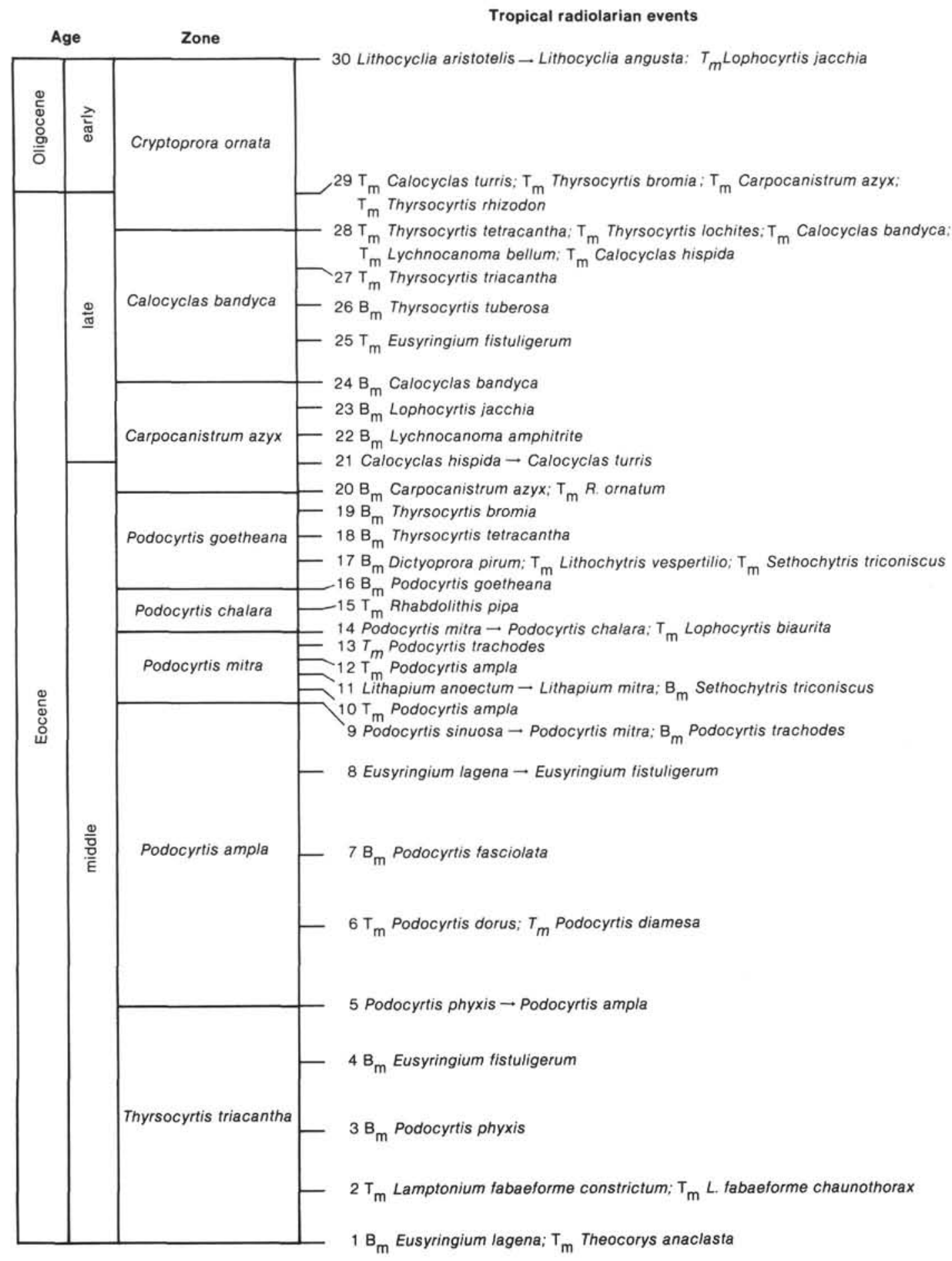

Figure 6. Upper Paleogene radiolarian events observed by Riedel and Sanfilippo (1978; in Saunders, et al., 1985) in tropical sections, and those observed in the upper Paleogene in Hole 612. Vertical scale for Zone column is proportional to absolute age (as in Fig. 2); the order of events within each zone is in the proper sequence, but no specific time value between events is implied. $\mathrm{B}_{\mathrm{m}}=$ morphologic base of species; $\mathrm{T}_{\mathrm{m}}=$ morphologic top; horizontal arrow $=$ evolutionary transition.

spongodiscids, porodiscids, litheliids, and coccodiscids are the predominant taxa. The first four groups are major components of high-latitude Paleogene faunas (such as those encountered on DSDP Legs 38,48 , and 81 in the North Atlantic); the last is important in tropical faunas. This assemblage is significantly different from those previously described from low-latitude localities in the
Atlantic and Caribbean drilled on DSDP Leg 4 (Riedel and Sanfilippo, 1970), Leg 10 (Riedel and Sanfilippo, 1973; Foreman, 1973), Leg 15 (Riedel and Sanfilippo, 1973), and Leg 44 (Weaver and Dinkelman, 1978).

The co-occurrence of taxa typically found at high and low latitudes in the New Jersey margin assemblage suggests the existence of a Paleogene north-south faunal 
Hole 612

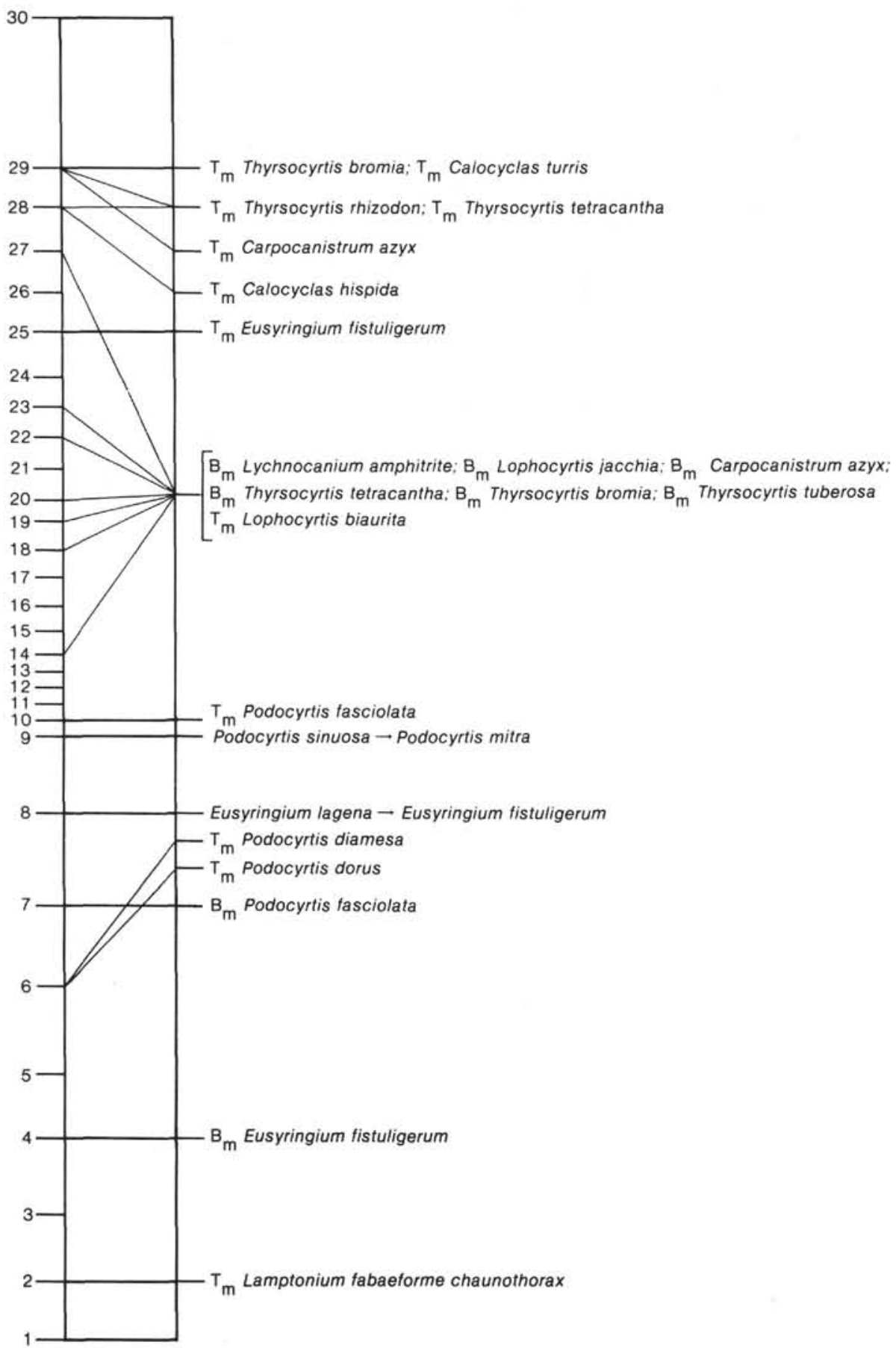

Figure 6 (continued).

gradient that probably reflected an environmental gradient (including such factors as temperature, insolation, etc.). Furthermore, Blueford $(1983,1984)$ and Blueford and King (1983) observed that spongy radiolarians are typical of shelf-water faunas in cold/temperate regions, both modern and ancient. Blueford and White (1984) applied this argument to a paleoenvironmental analysis of the Eocene Kreyenhagen Formation of California, in which they found that "porodiscids and spongodiscids dominate the radiolarian fauna, actinommids are common and nassellarians are of lesser importance." The presence of a large component of spongy radiolarians in the Atlantic margin deposits thus also suggests cool/temperate conditions along the Paleogene Atlantic margin.

\section{Neogene}

Compared with the Paleogene, radiolarians in the Neogene of the New Jersey margin are less abundant and 
more poorly preserved. The sandy Neogene lithologies indicate considerable detrital influx and terrigenous influence. The delta-influenced paleoenvironmental conditions associated with these lithologies may have been responsible for the diminished radiolarian fauna. Many taxa in the Neogene assemblage, including Dictyocoryne, Didymocyrtis, porodiscids, litheliids, and circular spongodiscids, are typical of spongy cold/temperate shelf-water assemblages (Blueford, 1983; Blueford and King, 1983), and here appear to be delta-related. Deep-dwelling taxa such as Cornutella, Bathropyramis, and Peripyramis are consistently present, however, indicating bathyal depths. In contrast, these taxa are virtually absent from on-shore Neogene Coastal Plain deposits which represent neritic paleoenvironments (Palmer, 1984).

\section{ACKNOWLEDGMENTS}

This study was initiated while the author was an NSF Graduate Fellow at Princeton University, and the manuscript was completed at the Ocean Drilling Program, Texas A\&M University. Research support at Princeton was obtained from the Tuttle Fund of the Department of Geology \& Geophysics. Sincere appreciation is extended to Wylie Poag for his encouragement of the author's work on Cenozoic radiolarians of the Atlantic margin. Thanks to BDJ for support in the laboratory, to Karen Benson for drafting the figures, to Jack Baldauf and Christain Auroux for reviewing a preliminary draft of the manuscript, and to C. Wylie Poag and Richard N. Benson for scientific reviews. Discussions with W. R. Riedel, A. Sanfilippo, and M. J. Westberg were valuable in the interpretation of results. Kevin Biddle of Exxon assisted in obtaining samples from ASP-15 cores. This is Ocean Drilling Program Contribution No. ODP/P-85/004.

\section{REFERENCES}

Benson, R. N., 1966. Recent Radiolaria from the Gulf of California [Ph. D. dissertation]. University of Minnesota, Minneapolis. 1972. Radiolarians-Site 114. In Laughton, A. S., Berggren, W. A., et al., Init. Repts. DSDP, 12: Washington (U.S. Govt. Printing Office), 324-325.

Berggren, W. A., Kent, D. V., and Flynn, J., 1985a. Paleogene geochronology and chronostratigraphy. In Snelling, N. J. (Ed.), Geochronology and the Geologic Time Scale. Spec. Publ. Geol. Soc. London, pp. 141-195.

Berggren, W. A., Kent, D. V., Flynn, J. J., and Van Couvering, J., 1985b. Cenozoic geochronology. Geol. Soc. Am. Bull., 96:14071418.

Bjørklund, K. R., 1976. Radiolaria from the Norwegian Sea, Leg 38 of the Deep Sea Drilling Project. In Talwani, M., Udintsev, G., et al., Init. Repts. DSDP, 38: Washington (U.S. Govt. Printing Office), 1101-1168.

Blueford, J. R., 1983. Distribution of Quaternary radiolarians in the Navarin Basin geologic province, Bering Sea. Deep-Sea Res. 30: 763-781.

Blueford, J. R., and King, C., 1983. Distribution of spongodiscidtype radiolarians in Recent sediments. Am. Assoc. Petrol. Geol. Bull., 67:425. (Abstract)

Blueford, J. R,. and White, L. D., 1984. Paleoceanographic interpretation of Eocene siliceous deposits from west-central California. In Blueford, J. R. (Ed.), Kreyenhagen Formation and Related Rocks. Pacific Section, Soc. Econ. Paleontol. Mineral., pp. 67-78.

Brandt, R. (in Wetzel, O.), 1935. Die Mikropalaeontologie des Heiligenhafener Kieseltones (Ober-Eozän) mit Beitragen von R. Brandt [Radiolarien] und F. Hustedt [Diatomeen]. Niedersaechs. Geol. Verhandl. Jahresber., 27:41-81.

Campbell, A. S., and Clark, B. L., 1944. Miocene radiolarian faunas from Southern California. Spec. Pap. Geol. Soc. Am., 51:1-76.

Chen, P., 1975. Antarctic Radiolaria. In Hayes, D. E., Frakes, L. A., et al., Init. Repts. DSDP, 28: Washington (U.S. Govt. Printing Office), 480-492.

Cita, M. B., Nigrini, C., and Gartner, S., 1970. Biostratigraphy. In Peterson, M. N. A., Edgar, N. T., et al., Init. Repts. DSDP, 2 : Washington (U.S. Govt. Printing Office), 391-411.
Ehrenberg, C. G., 1847. Über die mikroskopischen kieselschaligen Polycystinen als mächtige Gebirgsmasse von Barbados. Eine neue Anregung zur Erforschung des Erdlebens. Ber. Konig. Preuss. Akad. Wiss. (Berlin), pp. 40-60.

1854. Mikrogeologie: Leipzig (Leopold Voss).

1860. Über den Tiefgrund des stillen Oceans Zwischen Californien und den Sandwich-Inseln aus bis $156000^{\prime}$ Tiefe nach Lieut. Brookes. Monatsber. Konig. Preuss. Akad. Wiss. (Berlin), Jahre 1860:819-833.

1861. Über die Tiefgrund-Verhaltnisse des Oceans am Eingange der Davis-strasse und Island. Monatsber. Konig. Preuss. Akad. Wiss. (Berlin), Jahre 1861:275-315.

1873. Grossere Felsproben des Polycystinen-Mergel von Barbados mit weiteren Erlauterungen. Monatsber. Konig. Preuss. Akad. Wiss. (Berlin), Jahre 1873:213-263.

1875. Forsetzung der mikrogeologischen Studien als Gesammt-Uebersicht der mikroskoposchen Paläontologie gleichartig analysirter Gebirgsarten der Erde, mit specieller Rücksicht auf den Polycystinen-Mergel von Barbados. Abh. Konig. Preuss. Akad. Wiss. (Berlin), Jahre 1875:1-225.

Foreman, H. P., 1973. Radiolaria of Leg 10 with systematics and ranges for the families Amphipyndacidae, Artostrobiidae, and Theoperidae. In Worzel, J. L., Bryant, W., et al., Init. Repts. DSDP, 10: Washington, D.C. (U.S. Govt. Printing Office), 407-474.

Goll, R. M., 1968. Classification and phylogeny of Cenozoic Trissocyclidae (Radiolaria) in the Pacific and Caribbean basins. Part 1. J. Paleontol., 42:1409-1432.

Haeckel, E., 1887. Report on the Radiolaria collected by H.M.S. Challenger during the years 1873-76. Report on the Scientific Results of the Voyage of the H.M.S. Challenger. Zoology, 18:1-1803.

Harting, P., 1863. Bijdrage tot de kennis der mikroskopische fauna en flora van de Banda-Zee. Koninklijk Akademie Wetenschappen Amsterdam, Verhanalingen, 10:2-54.

Kling, S. A., 1973. Radiolaria from the eastern North Pacific, Deep Sea Drilling Project, Leg 18. In Kulm, L. D., von Huene, R., et al., Init. Repts. DSDP, 18: Washington (U.S. Govt. Printing Office), 617-671.

Kozlova, G. E., and Gorbovetz, A. N., 1966. Radiolaria of the Upper Cretaceous and upper Eocene deposits of the West Siberia Lowland. Tr. Vses. Nauch.-Issled. Geol.-Razv. Inst, 248:1-159.

Krasheninnikov, V. A., 1960. Nekotorye Radiolyarii Nizhnego i Srednego Eotsena Zapadnogo Predkavkazya. Min. Geol. i Okhr. Nedr SSSR, Vres. Nauch. Issled. Geol. Neft. Inst., 16:271.

Moore, T. C., Jr., 1972. Mid-Tertiary evolution of the radiolarian genus Calocycletta. Micropaleontology, 18:144-152.

Morley, J. J., and Hays, J. D., 1979. Cycladophora davisiana: A stratigraphic tool for Pleistocene North Atlantic and interhemisphere correlation. Earth Planet. Sci. Lett., 44:383-389.

Müller, J., 1858. Über die Thalassicollen, Polycystinen und Acanthometren des Mittelmeeres. Abh. Konig. Preuss. Akad. Wiss. (Berlin), Jahre 1858:1-62.

Nigrini, C., 1974. Cenozoic Radiolaria from the Arabian Sea, DSDP Leg 23. In Davies, T. A., Luyendyk, B. P., et al., Init. Repts. $D S D P, 26$ : Washington (U.S. Govt. Printing Office), 1051-1121. 1977. Tropical Cenozoic Artostrobiidae (Radiolaria). Micropaleontology, 23:241-269.

Palmer, A. A., 1984. Neogene radiolarians of the mid-Atlantic Coastal Plain: Biostratigraphic and paleoenvironmental analysis, and implications to shelf paleoceanography and depositional history [Ph.D. dissertation]. Princeton University, Princeton, New Jersey. 1986. Miocene radiolarian biostratigraphy, U.S. mid-Atlantic Coastal Plain. Micropaleontology, 32:19-31.

Petrushevskaya, M. G., 1972. Biostratigrafiya glubokovodnykh chetvertichnykh osadkov po dannym radiolyarievogo analyza. Okeanologiya, 12:71-86.

Poag, C. W., 1978. Stratigraphy of the Atlantic continental shelf and slope of the United States. Annu. Rev. Earth Planet. Sci., 6:251280.

1980. Foraminiferal stratigraphy, paleoenvironments, and depositional cycles in the outer Baltimore Canyon Trough. In Scholle, P. A. (Ed.), Geologic Studies of the COST No. B-3 Well, U.S. Mid-Atlantic Continental Slope Area. U.S. Geol. Surv. CircuIar, 833:44-65.

1984. Neogene stratigraphy of the submerged U.S. Atlantic margin. Paleogeogr., Paleoclimatol., Paleoecol., 47:103-127. 
1985. Depositional history and stratigraphic reference section for the central Baltimore Canyon Trough. In Poag, C. W. (Ed.), Geological Evolution of the United States Atlantic Margin: New York (Van Nostrand Reinhold), pp. 217-263.

Riedel, W. R., 1953. Mesozoic and late Tertiary Radiolaria of Rotti. J. Paleontol. 27:805-813.

1957. Radiolaria. A preliminary stratigraphy. Repts. Swedish Deep-Sea Exped., 6:59-96.

1958. Radiolaria in Antarctic sediments. Repts. B.A.N.Z. Antarctic Res. Exped., Ser. B, 6:217-255.

1959. Oligocene and lower Miocene Radiolaria in tropical Pacific sediments. Micropaleontology, 5:285-302.

Riedel, W. R., and Sanfilippo, A., 1970. Radiolaria, Leg 4, Deep Sea Drilling Project. In Bader, R. G., Gerard, R. D., et al., Init. Repts. $D S D P, 4$ : Washington (U.S. Govt. Printing Office), 503-575.

1971. Cenozoic Radiolaria from the western tropical Pacific, Leg 7. In Winterer, E. L., Riedel, W. R., et al., Init. Repts. DSDP, 7, Pt. 1: Washington (U.S. Govt. Printing Office), 1529 1672.

1973. Cenozoic Radiolaria from the Caribbean, Deep Sea Drilling Project Leg 15. In Edgar, N. T., Saunders, J. B., et al., Init. Repts. DSDP, 15: Washington (U.S. Govt. Printing Office), 705-751.

1977. Cainozoic Radiolaria. In Ramsay, A. T. S. (Ed.), Oceanic Micropaleontology: London (Academic Press), pp. 847-912.

1978. Stratigraphy and evolution of tropical Cenozoic radiolarians. Micropaleontology, 24:61-96.

Sanfilippo, A., Burckle, L. H., Martini, E., and Riedel, W. R., 1973. Radiolarians, diatoms, silicoflagellates and calcareous nannofossils in the Mediterranean Neogene. Micropaleontology, 19:209 234.

Sanfilippo, A., and Riedel, W. R., 1970. Post-Eocene "closed" theoperid radiolarians. Micropaleontology, 16:446-462.

1973. Cenozoic Radiolaria (exclusive of theoperids, artostrobiids and amphipyndacids) from the Gulf of Mexico, Deep Sea Drilling Project Leg 10. In Worzel, J. L., Bryant, W., et al., Init. Repts. DSDP, 10: Washington (U.S. Govt. Printing Office), 475611 .

1979. Radiolaria from the northeastern Atlantic Ocean, DSDP Leg 48. In Montadert, L., Roberts, D. G., et al., Init. Repts. DSDP, 48: Washington (U.S. Govt. Printing Office), 493511.

1980. A revised generic and suprageneric classification of the Artiscins (Radiolaria). J. Paleontol., 54:1008-1012.

1982. Revision of the radiolarian genera Theocotyle, Theocotylissa and Thyrsocyrtis. Micropaleontology, 28:170-188.

Sanfilippo, A., Westberg-Smith, M. J., and Riedel, W. R., 1985. Cenozoic Radiolaria. In Bolli, H. M., Saunders, J. B., and PerchNielsen, K. (Eds.), Plankton Stratigraphy: Cambridge (Cambridge University Press), pp. 631-712.

Saunders, J. B., Bernoulli, D., Muller-Merz, E., Oberhänsli, H., PerchNielsen, K., Riedel, W. R., Sanfilippo, A., and Torrini, R., Jr., 1985. Stratigraphy of the late middle Eocene to early Oligocene in the Bath Cliffs section, Barbados. Micropaleontology, 30:390425.

Schlee, J. S., 1981. Seismic stratigraphy of the Baltimore Canyon Trough. Am. Assoc. Pet. Geol. Bull., 65:26-53.

Sutton, H. J., 1896. Radiolaria: A new genus from Barbados. Am. Mon. Microsc. J., 17:61.

Weaver, F. M., and Dinkelman, M. G., 1978. Cenozoic radiolarians from the Blake Plateau and the Blake-Bahama Basin, DSDP Leg 44. In Benson, W. E., Sheridan, R. E., et al., Init. Repts. DSDP, 44: Washington (U.S. Govt. Printing Office), 865-886.

Westberg, M. J., and Riedel, W. R., 1978. Accuracy of radiolarian correlations in the Pacific Miocene. Micropaleontology, 24:1-23.

Date of Initial Receipt: 6 August 1985

Date of Acceptance: 28 February 1986

\section{APPENDIX}

Species List

The following is a list of Cenozoic radiolarian species identified in samples from the New Jersey Transect.
Artophormis barbadensis (Ehrenberg)

Calocyclas barbadensis Ehrenberg, 1873, p. 217; 1875, pl. 18, fig. 8.

Artophormis barbadensis (Ehrenberg), Riedel and Sanfilippo, 1970, p. 532 , pl. 13 , fig. 5 .

Artophormis gracilis Riedel, 1959, p. 300, pl. 2, figs. 12, 13.

Buryella clinata Foreman, 1973, p. 433, pl. 8, figs. 1-3; pl. 9, fig. 19.

Buryella tetradica Foreman, 1973, pl. 8, figs. 4, 5; pl. 9, figs. 13, 14.

Calocyclas hispida (Ehrenberg)

Anthrocyrtis hispida Ehrenberg, 1873, p. 216; 1875, pl. 8, fig. 2. Calocyclas hispida (Ehrenberg), Foreman 1973, p. 434, pl. 1, figs. 12-15; pl. 9, fig. 18.

Calocyclas turris Ehrenberg, 1873, p. $218 ; 1875$, pl. 18, fig. 7

Calocycletta serrata Moore, 1972, p. 148, pl. 2, figs. 1-3.

Calocycletta virginis (Haeckel) Calocyclas virginis Haeckel, 1887, p. 1381, pl. 74, fig. 4. Calocycletta virginis (Haeckel), Moore, 1972, p. 147, pl. 1, fig. 4.

Carpocanistrum azyx Sanfilippo and Riedel, 1973, p. 530, pl. 35, fig. 9.

Carpocanopsis bramlettei Riedel and Sanfilippo, 1971, p. 1597, p. 2G, figs. $8-14$, pl. 8 , fig. 7.

Carpocanopsis cingulata Riedel and Sanfilippo, 1971, p. 1597, pl. 2G, figs. $17-21$; pl. 8 , fig. 8 .

Ceratospyris articulata Ehrenberg, 1873, p. 218; Sanfilippo and Riedel, 1973 , p. 526, pl. 15, figs. $1-3$; pl. 31 , figs. $8,9$.

Cryptoprora ornata Ehrenberg, 1873, p. 222; 1875, pl. 5, fig. 8.

Cyclampterium leptetrum Sanfilippo and Riedel, 1970, p. 456, pl. 2, figs. $11,12$.

Cyclampterium longiventer Chen, 1975, p. 459, pl. 10, fig. 7.

Cyrtocapsella cornuta (Haeckel)

Cyrtocapsa cornuta Haeckel, 1887, p. 1513, pl. 78, fig. 9. Cyrtocapsella cornuta (Haeckel), Sanfilippo and Riedel, 1970, p. 453 , pl. 1, figs. 19, 20.

Cyrtocapsella tetrapera (Haeckel)

Cyrtocapsa tetrapera Haeckel, 1887, p. 1512, pl. 78, fig. 5.

Cyrtocaspella tetrapera (Haeckel), Sanfilippo and Riedel, 1970, p. 453 , pl. 1, figs. 16-18.

Diartus hughesi (Campbell and Clark)

Ommatocampe hughesi Campbell and Clark, 1944, p. 23, pl. 3, fig. 12.

Diartus hughesi (Campbell and Clark), Sanfilippo and Riedel, 1980, p. 1010.

Diartus petterssoni (Riedel and Sanfilippo)

Cannartus(?) petterssoni Riedel and Sanfilippo, 1970, p. 520, pl. 14 , fig. 3.

Diartus petterssoni (Riedel and Sanfilippo), Sanfilippo and Riedel, 1980 , p. 1010 , text-fig. $1 \mathrm{~h}$.

Dictyophimus craticula Ehrenberg, 1873, p. 223; Sanfilippo and Riedel, 1973 , p. 529 , pl. 19 , fig. 1 ; pl. 33, fig. 11.

Dictyoprora amphora (Haeckel) group

Dictyocephalus amphora Haeckel, 1887, p. 1305, pl. 62, fig. 4.

Dictyoprora amphora (Haeckel) group, Nigrini, 1977, p. 250, pl. 4 , figs. $1,2$.

Dictyoprora sp. aff. D. amphora (Haeckel) group Theocampe sp. aff. T. amphora (Haeckel) group, Foreman, 1973, p. 432, pl. 9, fig. 10.

Dictyoprora sp. aff. D. amphora (Haeckel) group, Nigrini, 1977, p. 250 , pl. 4 , fig. 3 .

Dictyoprora armadillo (Ehrenberg)

Eucyrtidium armadillo Ehrenberg, 1873, p. 225; 1875, p. 70, pl. 9, fig. 10.

Dictyoprora armadillo (Ehrenberg), Nigrini, 1977, p. 250, pl. 4, fig. 4.

Dictyoprora mongolfieri (Ehrenberg)

Eucyrtidium mongolfieri Ehrenberg, 1854, pl. 36, fig. 18, B lower; 1873 , p. 230.

Dictyoprora mongolfieri (Ehrenberg), Nigrini, 1977, p. 250, pl. 4, fig. 7.

Dictyoprora ovata (Haeckel)

Theocampe ovata Haeckel, 1887, p. 1416, pl. 69, fig. 16. Dictyoprora ovata (Haeckel), Nigrini, 1977, p. 251, pl. 4, figs. 5,6 .

Dictyoprora pirum (Ehrenberg)

Eucyrtidium pirum Ehrenberg, 1873, p. 232; 1875, pl. 10, fig. 14. Dictyoprora pirum (Ehrenberg), Nigrini, 1977, p. 251, pl. 4, fig. 8. 
Dictyoprora urceolus (Haeckel)

Dictyocephalus urceolus Haeckel, 1887, p. 1305.

Dictyoprora urceolus (Haeckel), Nigrini, 1977, p. 251, pl. 4, figs. 9, 10.

Didymocyrtis antepenultima (Riedel and Sanfilippo)

Ommatartus antepenultimus Riedel and Sanfilippo, 1970, p. 521, pl. 14 , fig. 4.

Didymocyrtis antepenultima (Riedel and Sanfilippo), Sanfilippo and Riedel, 1980, p. 1010.

Didymocyrtis avita (Riedel)

Panartus avitus Riedel, 1953, p. 808, fig. 7.

Didymocyrtis avita (Riedel), Sanfilippo and Riedel, 1980, p. 1010.

Didymocyrtis laticonus (Riedel)

Cannartus laticonus Riedel, 1959, p. 291, pl. 1, fig. 5.

Didymocyrtis laticonus (Riedel), Sanfilippo and Riedel, 1980, p. 1010, text-fig. le.

Didymocyrtis penultima (Riedel)

Panarium penultimum Riedel, 1957, p. 76, pl. 1, fig. 1.

Didymocyrtis penultima (Riedel), Sanfilippo and Riedel, 1980, p. 1010.

Didymocyrtis prismatica (Haeckel)

Pipettella prismatica Haeckel, 1887, p. 305, pl. 39, fig. 6.

Didymocyrtis prismatica (Haeckel), Sanfilippo and Riedel, 1980, p. 1010 , text-fig. 1c.

Didymocyrtis violina (Haeckel)

Cannartus violina Haeckel, 1887, p. 358.

Didymocyrtis violina (Haeckel), Sanfilippo and Riedel, 1980, p. 1010.

Eusyringium fistuligerum (Ehrenberg)

Eusyringium fistuligerium Ehrenberg, 1873, p. 229; 1875, pl. 9, fig. 3.

Eusyringium fistuligerum (Ehrenberg), Riedel and Sanfilippo, 1970, p. 527 , pl. 8 , figs. 8,9 .

Eusyringium lagena (Ehrenberg)

Lithopera lagena Ehrenberg, 1873, p. 241.

Eusyringium lagena (Ehrenberg), Foreman, 1973, p. 435, pl. 11, figs. 4,5 .

Lamprocyrtis neoheteroporos Kling, 1973, p. 639, pl. 5, figs. 17, 18; pl. 15 , figs. 4,5 .

Lamptonium fabaeforme chaunothorax Riedel and Sanfilippo, 1970, p. 524 , pl. 5 , figs. 8,9 .

Lamptonium obelix Sanfilippo and Riedel, 1979, p. 503, pl. 1, figs. $1,2$.

Liriospyris stauropora (Haeckel)

Trissocyclus stauropora Haeckel, 1887, p. 987, pl. 83, fig. 5 .

Liriospyris stauropora (Haeckel), Goll, 1968, p. 1431, pl. 75, figs. $1-3,7$, text-fig. 9.

Lithapium anoectum Riedel and Sanfilippo, 1970, p. 520, pl. 4, figs. 4,5 .

Lithapium mitra (Ehrenberg)

Cornutella mitra Ehrenberg, 1873, p. 221.

Lithapium mitra (Ehrenberg), Riedel and Sanfilippo, 1970, p. 520, pl. 4 , figs. 6,7 .

Lithapium plegmacantha Riedel and Sanfilippo, 1970, p. 520, pl. 4, figs. 2, 3; Sanfilippo and Riedel, 1973, pp. 516-517, pl. 3, figs. 1, 2 ; pl. 24, figs. 8,9 .

Lithochytris vespertilio Ehrenberg, 1873, p. 239; Riedel and Sanfilippo, 1970 , p. 528 , pl. 9 , figs. $8,9$.

Lithocyclia angusta (Riedel)

Trigonactura angusta Riedel, 1959, p. 292, pl. 1, fig. 6 .

Lithocyclia angusta (Riedel), Riedel and Sanfilippo, 1970, p. 522, pl. 13 , figs. 1,2 .

Lithocyclia artstotelis (Ehrenberg)

Astromma aristotelis Ehrenberg, 1847, p. 55, fig. 10.

Lithocyclia aristotelis (Ehrenberg) group, Riedel and Sanfilippo, 1970 , p. 522.

Lithocyclia ocellus Ehrenberg group

Lithocyclia ocellus Ehrenberg, 1854, pl. 36, fig. 30; Riedel and Sanfilippo, 1970 , p. 522 , pl. 5, figs. 1,2 .

Lithopera renzae Sanfilippo and Riedel, 1970, p. 454, pl. 1, figs. 21$23,27$.

Lophocyrtis biaurita (Ehrenberg)

Eucyrtidium biauritum Ehrenberg, 1873, p. 226.
Lophocyrtis biaurita (Ehrenberg), Cita, Nigrini and Gartner, 1970, p. 404 , pl. 2, figs. I-K.

Lophocyrtis jacchia (Ehrenberg)

Thyrsocyrtis jacchia Ehrenberg, 1873, p. 261.

Lophocyrtis jacchia (Ehrenberg), Riedel and Sanfilippo, 1971, p.

1594 , pl. 3C, figs. 4 , 5; pl. 7, fig. 16.

Lychnocanoma amphitrite Foreman, 1973, p. 437, pl. 11, fig. 10.

Periphaena decora Ehrenberg, 1873, p. 246; 1875, pl. 28, fig. 6.

Periphaena delta Sanfilippo and Riedel, 1973, p. 523, pl. 8, figs. 11, 12 ; pl. 27 , figs. 6,7 .

Periphaena tripyramis tripyramis (Haeckel)

Triactus tripyramis Haeckel, 1887, p. 432, pl. 33, fig. 6 .

Periphaena tripyramis tripyramis (Haeckel), Sanfilippo and Riedel, 1973, p. 523, pl. 9, figs. 7-9.

Periphaena tripyramis triangula (Sutton)

Phacotriactis triangula Sutton, 1896, p. 61.

Periphaena tripyramis triangula (Sutton), Sanfilippo and Riedel, 1973, p. 523, pl. 9, figs. 10, 11.

Phormocyrtis striata exquisita (Kozlova)

Podocyrtis exquisita Kozlova In Kozlova and Gorbovets, 1966, p. 106, pl. 17, fig. 2.

Phormocyrtis striata exquisita (Kozlova), Foreman, 1973, p. 438, pl. 7, figs. 1-4, 7, 8; pl. 12, fig. 5 .

Phormocyrtis striata striata Brandt

Phormocyrtis striata Brandt, 1935, p. 55, pl. 9, fig. 12.

Phormocyrtis striata striata Brandt-Foreman 1973, p. 438, pl. 7, figs. $5,6,9$.

Phormostichoartus corbula (Harting)

Lithocampe corbula Harting, 1863, p. 12, pl. 1, fig. 21.

Phormostichoartus corbula (Harting), Nigrini, 1977, p. 252, pl. 1, fig. 10.

Podocyrtis ampla Ehrenberg

Podocyrtis ampla Ehrenberg, 1873, p. 248; 1875, pl. 16, fig. 7.

Podocyrtis (Podocyrtis) ampla Ehrenberg, Riedel and Sanfilippo, 1970 , p. 533 , pl. 12 , figs. 7,8 .

Podocyrtis chalara Riedel and Sanfilippo

Podocyrtis (Lampterium) chalara Riedel and Sanfilippo, 1970, p. 535 , pl. 12, figs. $2,3$.

Podocyrtis diamesa Riedel and Sanfilippo, emend. Sanfilippo and Riedel

Podocyrtis diamesa Riedel and Sanfilippo, 1970, p. 523, pl. 12, fig. 4 .

Podocyrtis dorus Sanfilippo and Riedel, 1973, p. 531, pl. 35, figs. 1214.

Podocyrtis fasciolata Nigrini

Podocyrtis ampla fasciolata Nigrini, 1974, p. 1069, pl. 1K, figs. 1, 2; pl. 4, figs. 2, 3 .

Podocyrtis fasciolata Nigrini-Sanfilippo et al., 1985.

Podocyrtis mitra Ehrenberg, 1854, pl. 36, fig. B20; Riedel and Sanfilippo, 1970, p. 534, pl. 11, figs. 5, 6.

Podocyrtis sinuosa Ehrenberg

Podocyrtis sinuosa Ehrenberg, 1873, p. 253; 1875, pl. 15, fig. 5 . Podocyrtis (Lampterium) sinuosa Sanfilippo et al., 1985.

Pterocorys hertwigii (Haeckel)

Eucyrtidium hertwigii Haeckel, 1887, p. 1491, pl. 80, fig. 12. Pterocorys hertwigii (Haeckel), Petrushevskaya, 1972, fig. 1 (10).

Pterocorys zancleus (Müller)

Eucyrtidium zanclaeum Müller, 1858, p. 41, pl. 6, figs. 1-3.

Theoconus zancleus (Müller), Benson, 1966, p. 482, pl. 33, fig. 4.

Spongaster berminghami (Campbell and Clark)

Spongasteriscus berminghami Campbell and Clark, 1944, p. 10, pl. 5 , figs. 1,2 .

Spongaster berminghami (Campbell and Clark), Sanfilippo and Riedel, 1973, p. 524.

Spongaster tetras Ehrenberg, 1860, p. 833; Riedel and Sanfilippo, 1971, p. 1589 , pl. $1 \mathrm{D}$, figs. 2,4 .

Spongatractis balbis Sanfilippo and Riedel, 1973, p. 518, pl. 2, figs. $1-3$; pl. 25 , figs. $1,2$.

Spongatractus pachystylus (Ehrenberg)

Spongosphaera pachystyla Ehrenberg, 1873, p. 256; 1875, pl. 26, fig. 3 .

Spongatractus pachystylus (Ehrenberg), Sanfilippo and Riedel,

1973, p. 519, pl. 2, figs. 4-6; pl. 25, fig. 3. 
Stichocorys delmontensis (Campbell and Clark)

Eucyrtidium delmontense Campbell and Clark, 1944, p. 56, pl. 7, figs. 19,20 .

Stichocorys delmontensis (Campbell and Clark), Sanfilippo and Riedel, 1970, p. 451, pl. 1, fig. 9.

Stichocorys peregrina (Riedel)

Eucyrtidium elongatum peregrinum Riedel, 1953, p. 812, pl. 85, fig. 2 .

Stichocorys peregrina (Riedel), Sanfilippo and Riedel, 1970, p. 451, pl. 1 , fig. 10.

Stichocorys wolffii Haeckel, 1887, p. 1479, pl. 80, fig. 10 .

Theocalyptra davisiana (Ehrenberg)

Cycladophora? davisiana Ehrenberg, 1861, p. 297.

Theocalyptra davisiana (Ehrenberg), Riedel, 1958, p. 239, pl. 4, figs. 2,3 ; text-fig. 10.

Theocorys anapographa Riedel and Sanfilippo, 1970, p. 530, pl. 10, fig. 4; Foreman, 1973, p. 440, pl. 5, figs. 9, 10.

Theocotyle conica Foreman

Theocotyle (Theocotyle) cryptocephala(?) conica Foreman, 1973, p. 440 , pl. 4 , fig. $11 ;$ pl. 12, figs. $19,20$.

Theocotyle conica Foreman-Sanfilippo and Riedel, 1982, pp. $177-178$, pl. 2, fig. 13.

Theocotyle cryptocephala (Ehrenberg)

Eucyrtidium cryptocephalum Ehrenberg, 1873, p. 227; 1875, pl. 11 , fig. 11 .

Theocotyle cryptocephala (Ehrenberg), Sanfilippo and Riedel, 1982, p. 178 , pl. 2 , figs. 4-7.

Theocotyle nigrinae (Riedel and Sanfilippo)

Theocorys sp. Nigrini in Cita et al., 1970, pl. 2, fig. L.

Theocotyle nigrinae Sanfilippo and Riedel, 1982, p. 178, pl. 2, figs. 1-3.

Theocotylissa ficus (Foreman)

Eucyrtidium ficus Ehrenberg, 1873, p. 228; 1875, pl. 11, fig. 19. Theocotylissa ficus Foreman-Sanfilippo and Riedel, 1982, pp. 180-181, pl. 2, figs. 19-20.
Theocyrtis annosa (Riedel)

Phormocyrtis annosa Riedel, 1959, p. 295, pl. 2, fig. 7.

Thyrsocyrtis annosa (Riedel), Riedel and Sanfilippo, 1970, p. 535, pl. 15 , fig. 9 .

Theocyrtis tuberosa Riedel, 1959, p. 298, pl. 2, figs. 10, 11.

Theocyrtis sp. cf. T. tuberosa

Theocyrtis sp. ancestral to T. tuberosa, Riedel and Sanfilippo, 1978, p. 78 , pl. 1, fig. 10 .

Thyrsocyrtis bromia Ehrenberg

Thyrsocyrtis bromia Ehrenberg, 1873, p. 260; 1875, pl. 12, fig. 2. Thyrsocyrtis (Thyrsocyrtis) bromia Ehrenberg-Sanfilippo and Riedel, 1982 , p. 172 , pl. 1, figs. 17-20.

Thyrsocyrtis hirsuta (Krasheninnikov) Podocyrtis hirsutus Krasheninnikov, 1960, p. 300, pl. 3, fig. 16. Thyrsocyrtis (Thyrsocyrtis) hirsuta (Krasheninnikov), Sanfilippo and Riedel, 1982, p. 173, pl. 1, figs. 3-4.

Thyrsocyrtis rhizodon Ehrenberg Thyrsocyrtis rhizodon Ehrenberg, 1873, p. $262 ; 1875$, pl. 12, fig. 1.

Thyrsocyrtis (Thyrsocyrtis) rhizodon Ehrenberg-Sanfilippo and Riedel, 1982, pp. 173-174, pl. 1, figs. 14-16; pl. 3, figs. 12-17.

Thryscocyrtis tensa Foreman Thyrsocyrtis(?) sp. Foreman, 1973, pl. 3, figs. 18-19; pl. 13, fig. 2. Thyrsocyrtis (Pentalacorys) tensa Foreman-Sanfilippo and Riedel, 1982 , p. 176 , pl. 1 , figs. $6-7$; pl. 3 , figs. $1,2$.

Thyrsocyrtis tetracantha (Ehrenberg) Podocyrtis tetracantha Ehrenberg, 1873, p. 254; 1875, pl. 13, fig. 2.

Thyrsocyrtis (Pentalacorys) tetracantha (Ehrenberg), Sanfilippo and Riedel, 1982, p. 176, pl. 1, figs. 11-12; pl. 3, fig. 10.

Thyrsocyrtis triacantha (Ehrenberg) Podocyrtis triacantha Ehrenberg, 1873, p. 254; 1875, pl. 13, fig. 4. Thyrsocyrtis (Pentalacorys) triacantha (Ehrenberg), Sanfilippo and Riedel, 1982 , pp. $176-177$, pl. 1, figs. $8-10$; pl. 3, figs. 3, 4 .

Tristylospyris triceros (Ehrenberg) Ceratospyris triceros Ehrenberg, 1873, p. 220.

Tristylospyris triceros (Ehrenberg), Haeckel, 1887, p. 1033. 